Saint Louis University School of Law

Scholarship Commons

All Faculty Scholarship

2011

Beyond Profit: Rethinking Corporate Social Responsibility and Greenwashing After the BP Oil Disaster

Miriam A. Cherry

Judd F. Sneirson

Follow this and additional works at: https://scholarship.law.slu.edu/faculty

Part of the Banking and Finance Law Commons, and the Business Organizations Law Commons 


\title{
Beyond Profit: Rethinking Corporate Social Responsibility and Greenwashing After the BP Oil Disaster
}

\author{
Miriam A. Cherry* \\ Judd F. Sneirson ${ }^{\dagger}$
}

\begin{abstract}
The explosion of the BP-leased Deepwater Horizon and subsequent oil spill stand as an indictment not just of our national energy priorities and environmental law enforcement; they equally represent a failure of Anglo-American corporate law and what passes for corporate social responsibility in business today. Using BP and the disaster as a compelling case study, this Article examines green marketing and corporate governance and identifies elements of each that encourage firms to engage only superficially in corporate social responsibility yet trumpet those efforts to eager consumers and investors. This Article then proposes reforms and protections designed to increase corporate social responsibility, root out greenwashing, and recognize liability for corporate social responsibility frauds on consumers and investors. One of these protections derives from the newly enacted Dodd-Frank Act, whose Bureau of Consumer Financial Protection could play a leading role in policing fraudulent claims of corporate social responsibility.
\end{abstract}

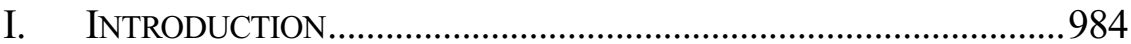

II. THE REALITY: AN OVERVIEW OF THE BP DISASTER ...................988

A. The Deepwater Horizon Explosion ...................................988

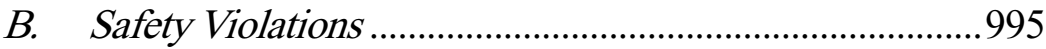

III. ThE MYTH: BP's History AND “BEYOND PETROLEUM”

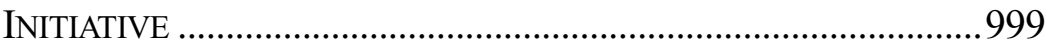

A. History, Cast of Characters, and Corporate Culture ..........999

B. The "Beyond Petroleum" Advertising Campaign............1002

C. Former BP CEO Lord John Browne's Memoir ................ 1004

D. Reception of the BPAdvertising Campaign.................... 1007

(C) 2011 Miriam A. Cherry and Judd F. Sneirson.

Visiting Professor, Appointed Professor of Law, St. Louis University Law School; Associate Professor of Law, University of the Pacific, McGeorge School of Law; B.A. 1996, Dartmouth College; J.D. 1999, Harvard Law School.

$\dagger \quad$ Visiting Professor, Hofstra University School of Law; B.A. 1992, Williams College; J.D. 1996, University of Pennsylvania.

The authors wish to acknowledge Anne Bloom, Adrienne Davis, Monica Eppinger, Chad Flanders, Victor Fleischer, Aya Gruber, Dayna Matthew, Scott Moss, Paul Ohm, Robert L. Rogers, Rachael Salcido, Andrew Schwartz, Constance Z. Wagner, and Jarrod Wong for their insights. Our appreciation to Kristen Henke, Matthew Pinkerton, and Joshua Ebersole for their excellent research assistance. Finally, thank you to the editors of the Tulane Law Review for their hard work on this symposium issue. 
IV. CORPORATE LAW's ROLE IN THE BP OIL SPILL .........................1009

A. Levels of Corporate Social Responsibility........................1010

B. Shareholder Primacy and Profit ......................................1015

C. Moving Beyond Profit ....................................................1021

V. SOlutions: TOWARD A SUBSTANTIVE THEORY OF

CORPORATE SOCIAL RESPONSIBILITY ....................................... 1025

A. A Cause of Action for "Greenwashing" and "Faux

CSR"....

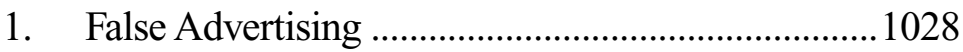

2. Securities Fraud ....................................................... 1030

3. The Dodd-Frank Act and the Bureau of

Consumer Financial Protection.................................1033

4. A Private Certification Model..................................1034

5. Counterarguments and Rebuttal................................1035

B. Reforming Profit Maximization......................................1037

VI. CONCLUSION 1038

\section{INTRODUCTION}

The BP oil spill represents a failure of more than just environmental law and the functioning of government agencies charged with overseeing deepwater drilling; ${ }^{1}$ corporate law, corporate governance, and corporate social responsibility (CSR) doctrine are equally to blame for the unprecedented disaster. Indeed, the spill implicates fundamental questions of how corporations are governed, how they present themselves to the public, and the goals they are supposed to achieve.

The tragic explosion and oil spill revealed a corporate culture at BP that had consistently neglected worker safety and environmental standards. BP had a dismal safety record, with many accidents that could have been avoided through better equipment maintenance and increased precautions. ${ }^{2}$ Ironically, the company at the same time mounted a highly successful advertising campaign, portraying itself as environmentally friendly, or at the very least not as bad as other oil

1. See Karla Urdaneta, Transboundary Petroleum Reservoirs: A Recommended Approach for the United States and Mexico in the Deepwaters of the Gulf of Mexico, 32 Hous. J. INT'L L. 333, 346 n.52 (2010) (describing the regulatory role of the Minerals Management Service in deepwater exploration). See generally Rachael E. Salcido, Offshore Federalism and Ocean Industrialization, 82 TUL. L. REV. 1355 (2008) (providing an account of conflicting structures of regulation of offshore activities).

2. See infra Part II.B. 
companies, and a champion of environmental causes. ${ }^{3}$ The marketing worked perfectly: BP went from a staid middle-of-the-pack oil company to one that consistently ranked in the top-ten most profitable multinational corporations in the world. It even ranked highly for its treatment of employees and became a darling of corporate social responsibility advocates. ${ }^{4}$

This Article examines this glaring inconsistency: the disconnect between how BP portrayed itself in the public sphere and how it actually behaved when its image was not at stake. It is a fascinating case study in that BP's advertising image was so strikingly different from the harsh realities of its environmental and safety record. It seems that BP's benevolence was limited primarily to areas that would be profitable for the firm's shareholders; it did not engage in CSR beyond that level and importantly did not act in socially responsible ways where there would be no profit or public relations upside.

Part of the problem lies in what some term "greenwashing" and what we dub "faux CSR." By greenwashing, a corporation might increase its sales or boost its brand image through environmental rhetoric, but at the same time either pollute the environment or decline to spend money on the environment, employee welfare, or otherwise honor its commitments to other constituencies. ${ }^{5}$ CSR's detractors

3. See Helene Cooper \& John M. Broder, BP's Ties to Agency Are Long and Complex, N.Y. Times, May 26, 2010, at A14 (noting that in 2007 BP had provided Lawrence Berkeley National Laboratory with a $\$ 500$ million grant to develop alternative energy sources; the recipient of the grant, Dr. Steven Chu, is now President Obama's energy secretary); Joe Stephens, Oil Spill Threatens To Stain Alliances; Environmental Nonprofits Face Potential Backlash as Supporters Learn of Ties to BP, WASH. Post, May 24, 2010, at A1 (detailing contributions from BP to nonprofit Nature Conservancy, and noting that "BP has been a major contributor to a Conservancy project aimed at protecting Bolivian forests"); id. ("In 2006, BP gave the organization 655 acres in York County, Va., where a state wildlife management area is planned. In Colorado and Wyoming, the Conservancy has worked with BP to limit environmental damage from natural gas drilling.").

4. According to the Wall Street Journal:

BP ... is now watching the halo created by a decade of smart advertising vanish as a mammoth oil slick makes its way across the Gulf of Mexico. BP's 'Beyond Petroleum' campaign had positioned the company on the green side of energy development. But its sunken drilling platform - and the resulting environmental catastrophe - has sent it firmly back into dirty carbon company territory.

Peter D. Hart \& Dan McGinn, Advice for BP’s Reputation Crisis, WALl St. J., May 27, 2010, at A19. BP has indeed fallen from grace as a result of the oil spill, garnering a "devastating 4-to-1 negative-to-positive ratio on feelings about the company." Id.; Ron Lieber, Driving Past the BP Station, and Tilting at Windmills, N.Y. TiMES, June 12, 2010, at B1 (noting consumer boycotts of BP gas stations).

5. See, e.g., Tom Wright, False "Green” Ads Draw Global Scrutiny, Wall ST. J., Jan. 30, 2008, at B4. But see Lisa M. Fairfax, Easier Said Than Done? A Corporate Law Theory for Actualizing Social Responsibility Rhetoric, 59 FLA. L. REV. 771, 795-96 (2007) (arguing 
come from all corners: those on the right claim that businesses should stick to core efficiencies and guarantee shareholder returns; ${ }^{6}$ and those on the left argue that CSR is an ineffective half-measure that will coopt any long-lasting or meaningful social change. ${ }^{7}$ But critics of CSR, both from the right and from the left, agree that greenwashing poses problems for consumers, investors, and businesses, and that there currently are no ready solutions for policing CSR claims. ${ }^{8}$ We posit that the accuracy of CSR information is important for efficient securities markets and informed consumer choice. Further, if faux CSR is allowed to flourish, it will ultimately undermine any attempts at substantive CSR, which will only be met with cynicism.

This Article therefore explores the ways in which corporate law doctrine could better serve companies wishing to become more socially responsible. In doing so, we join the ranks of previous commentators who have advocated for more comprehensive and substantive standards for CSR programs. ${ }^{9}$ We suggest a number of possibilities to achieve this goal, including: private standard-setting by independent organizations or other watchdogs; remedies under false advertising laws; claims under the securities fraud laws; and the newly

provocatively and interestingly, based on psychological research, that corporations are more likely to "buy in" to CSR philosophies the more the rhetoric is repeated).

6. See Alan C. Neal, Corporate Social Responsibility: Governance Gain or LaissezFaire Figleaf?, 29 COMP. LAB. L. \& POL'Y J. 459, 464 (2008) (providing big picture overview of the debate regarding CSR).

7. See, e.g., Kellye Y. Testy, Linking Progressive Corporate Law with Progressive Social Movements, 76 TUL. L. REv. 1227, 1229-30 (2002) (quoting feminist theorist Audre Lorde and arguing that the use of private ordering in this context may not provide a radical enough change).

8. Several articles detail the history of the CSR movement at some length. See, e.g., Douglas M. Branson, Corporate Governance "Reform" and the New Corporate Social Responsibility, 62 U. PITT. L. REV. 605 (2001); Richard Marens, The Hollowing Out of Corporate Social Responsibility: Abandoning a Tradition in an Age of Declining Hegemony, 39 McGeorge L. Rev. 851 (2008); Joe W. (Chip) Pitts III, Corporate Social Responsibility: Current Status and Future Evolution, 6 Rutgers J.L. \& PuB. Pol'y 334 (2009); Judd F. Sneirson, Doing Well by Doing Good: Leveraging Due Care for Better, More Socially Responsible Corporate Decisionmaking, 3 CORP. GOVERnANCE L. REv. 438, 444-50 (2007); C.A. Harwell Wells, The Cycles of Corporate Social Responsibility: An Historical Retrospective for the Twenty-First Century, 51 KAN. L. REv. 77 (2002).

9. See Janet E. Kerr, The Creative Capitalism Spectrum: Evaluating Corporate Social Responsibility Through a Legal Lens, 81 TEMP. L. REV. 831 (2008); Michael R. Siebecker, Corporate Speech, Securities Regulation, and an Institutional Approach to the First Amendment, 48 WM. \& MARY L. ReV. 613 (2006); Cynthia A. Williams, The Securities and Exchange Commission and Corporate Social Transparency, 112 HARV. L. REV. 1199, 12931306 (1999) (proposing that the SEC mandates disclosure of environmental information, thus providing a check against inflated advertising claims). 
established Bureau of Consumer Financial Protection, which could play a major role in policing CSR claims.

In the first half of this Article, we define and explore the reality versus the myth of BP. Part II describes the reality, providing an overview of the oil spill in the Gulf of Mexico and discussing the history of safety violations at BP, including recent incidents in Alaska, and the explosion of the Texas City, Texas, refinery that killed fifteen workers and that resulted in a massive fine from the Occupational Safety and Health Administration (OSHA). In Part III, we turn to the myth - the "Beyond Petroleum" marketing campaign, and the CSR rhetoric from Lord John Browne, BP's former CEO who spearheaded the advertisements. Our goal is to provide the facts that dramatically illustrate the problem: that a company can claim to be socially responsible, convince many people to believe and rely upon that claim, and yet act in a way that is anything but socially responsible.

Having described the problem in detail, we turn in Part IV to its causes and potential solutions. After describing CSR in general terms and noting the various levels at which firms may practice it, we analyze the corporate law features that contributed to the discrepancy between BP's advertising and reality. Chief among them is the drive to maximize shareholder profits, which can lead to corporate decisions to skimp on safety to save time and money and flout laws and regulations. Part IV also challenges this premise, arguing that American and British corporate laws do not require such a shareholder focus.

In Part V, we envision how the BP case study could be used as an opportunity for better corporate governance. Current law, by focusing only on short-term shareholder value, validates a very surface or shallow view of CSR, in which acts with positive externalities are undertaken only for their advertising potential. Instead we believe that additional policing of CSR is needed. Some commentators have advocated for more complete disclosure of environment-related performance, while others have argued for expanded causes of action for either false advertising (for consumers) or securities fraud (for investors). Another promising avenue that we explore rests with the newly created Bureau of Consumer Financial Protection. Created by the Dodd-Frank Act in the summer of 2010, the agency's enabling statute contains a specific charge to educate investors about the financial products they purchase; such language may provide another strategy for policing faux CSR claims. 


\section{The REALITY: AN OVERVIEW OF THE BP DisAster}

During the summer of 2010, live television footage showing oil gushing into the Gulf of Mexico became all too tragically familiar to the American public. ${ }^{10}$ In the days, weeks, and months following the Deepwater Horizon explosion, ${ }^{11}$ a more complete description of what happened unfolded in the mainstream media. In this Part, we provide a brief factual overview of the disaster and BP's subsequent attempts to stop oil from flowing into the Gulf. From there, we turn to BP's record of environmental and worker safety, which was unfortunately lacking.

\section{A. The Deepwater Horizon Explosion}

On April 20, 2010, the Deepwater Horizon, a drilling rig owned by Transocean and leased by BP to explore the Macondo oil field, exploded, caught fire, and sank. The accident killed eleven workers, while the others on the rig were saved by a supply ship; the attached well began to spew oil into the Gulf at an alarming rate. ${ }^{12}$ Although the causes of the disaster are still under investigation, ${ }^{13} \mathrm{BP}$ initially blamed Transocean; Transocean blamed Cameron, a company that manufactured a valve in the malfunctioning blowout preventer, ${ }^{14}$ in

10. Hank Stuever, BP Presents: One Slick Horror Film, WASH. Post, May 26, 2010, at $\mathrm{C} 1$ ("Spillcam combines the dread of horror films with the monotony of Andy Warhol's eight-hour silent movie of the Empire State Building. There is no sound and nothing happens, except the inexorable, unending flow. You watch a little, and then a little more, and then you can't stop watching as a steady plume of dark brown oil belches upward from the floodlit, rocky ocean floor.... The angle occasionally changes but the focus is always the leak.").

11. There does not seem to be a consensus on what to call the oil spill. The news media has used the terms "Deepwater Horizon Spill," "The Gulf Oil Spill," and "BP Oil Spill." Paul Farhi, The Branding of the Gulf Coast Oil Spill Could Be an Epic Problem for $B P$, WASH. Post, May 6, 2010, at $\mathrm{C} 1$. We use the various names interchangeably throughout this Article.

12. Russell Gold, Guy Chazan \& Ben Casselman, Oil Spills into Gulf After Rig Disaster, Wall St. J., Apr. 26, 2010, at A4; Steven Mufson \& David A. Fahrenthold, Oil Executives Pass the Blame for Spill, WASH. Post, May 12, 2010, at A6 (noting details of the rescue of the workers).

13. Ben Casselman \& Russell Gold, Unusual Decisions Set Stage for BP Disaster, WALl ST. J., May 27, 2010, at A1 (describing series of events and decisions that led up to the explosion).

14. In congressional testimony, BP officials admitted that one of the control pods for the blowout preventer had dead batteries. See Steven Mufson \& Joel Achenbach, BP Inserts Tube, Diverts Some Oil, WASH. Post, May 17, 2010, at A1. In a letter written by Transocean and signed by a BP representative, BP agreed to a replacement of a key part of the blowout preventer, even though "doing so would reduce redundancies and increase risks on the drilling rig." Steven Mufson, BP Agreed in 2004 to Parts Changes on Drilling Rig, Letter Says, WASH. POST, May 23, 2010, at A4. 
addition to Halliburton, which a day earlier had pumped concrete into the well. ${ }^{15}$ Representatives Henry Waxman and Bart Stupak asserted that BP compromised safety in order to reduce the amount of time and money it spent excavating the well. ${ }^{16}$ Others have blamed the Interior Department's Minerals Management Service for merely rubberstamping BP's drilling projects ${ }^{17}$ and failing to require that BP have an

In an article in the November-December 2006 issue of Drilling Contractor, Gary Leach of Transocean and Bob Judge, chief engineer of Hydril, a GE unit that makes blowout preventers, said 'substantial savings' were possible by leaving a test valve on the blowout preventer and turning it upside down to avoid having to withdraw pipe for testing. They said companies could save 12.5 hours or $\$ 260,000$ of rig time with each test.

Steven Mufson, High Drilling Costs for Deepwater Horizon Pressured BP To Save Time, WASH. Post, May 28, 2010, at A8. A federal investigation conducted by the U.S. Coast Guard and the Bureau of Ocean Energy Regulation and Enforcement heard testimony that "workers detected a leak in the hydraulic system that controls the blowout preventer" and reported it to BP management in Houston, but that the information never made it into required reports that BP sent to the Minerals Management Service. Ben Casselman, Supervisor Says Flaw Was Found in Key Safety Device, WALl ST. J., July 21, 2010, at A7.

15. Dana Milbank, BP Needs a Crude Awakening, WASH. Post, May 12, 2010, at A2 ("In a pair of Senate hearings Tuesday, BP's McKay traded blame with the oil platform operator, Transocean, and drilling contractor Halliburton. Their finger-pointing led one senator to compare them to children blaming one another for the baseball that went through the neighbor's window.'); Steven Mufson \& Michael D. Shear, Pressure Grows for Action by $B P$, WASH. POST, May 1, 2010, at A1.

16. Neil King Jr. \& Russell Gold, BP Crew Focused on Costs: Congress, Wall St. J., June 15, 2010, at A1 ("Time after time, it appears that BP made decisions that increased the risk of a blowout to save the company time or expense." (quoting letter from Reps. Waxman and Stupak)). Congressional hearings have also noted that there was an alarm system in place, but that it had apparently been disabled because the company did not want anyone to be disturbed by false alarms. Russell Gold \& Ben Casselman, Alarm Was Disabled Before BP Blast, WALL ST. J., July 24, 2010, http://online.wsj.com/article/SB100014240527487032 $94904575385160342490350 . \mathrm{html}$. In addition, congressional investigators found that BP had chosen a riskier well design, the "long string" design, which was less costly than the alternative liner-tieback design. Russell Gold \& Tom McGinty, BP Relied on Cheaper Wells - Analysis Shows Oil Giant Used "Risky" Design More Often Than Most Peers, WALL ST. J., June 19-20, 2010, at A1.

17. MMS has now been renamed the Bureau of Ocean Energy Management Regulation and Enforcement, and it would seem that, under its new director, the troubled agency is attempting to make a fresh start. Many of the agency workers were formerly employed in the oil and gas industries, and there were charges of agency capture, or to put it more colorfully, that the agency is "in bed" with the industry. MMS employees were, in fact, accused of literally being in bed with oil industry executives, as the Interior Department's Inspector General found a culture of ethical failure exemplified by the Lakewood Colorado sex scandal. See, e.g., Tom LoBianco, Bromwich Vows To Root Out and Fire Interior Workers Too Close to Industry, Inside ENERGY with FEDERAL LANDS No. 4 (June 28, 2010), available at 2010 WNLR 13960331. Later investigation revealed that only a week before the explosion, BP had three rapid-fire filings changing the proposed method of drilling with MMS. These revisions were approved quickly, one within five minutes of submission to Minerals Management Service. Russell Gold, Ben Casselman \& Maurice Tamman, Permit Snafus on BP's Oil Well, WALl ST. J., June 1, 2010, at A1. Further, these changes were 
appropriate response plan in place in the event of a spill. ${ }^{18}$ The congressional investigation found that BP officials had chosen the riskier type of well casing only days before the blowout. ${ }^{19}$ An internal BP document "highlights a series of abnormal indicators - about pipeline pressure and the flow of drilling fluids in the five hours before the explosion - that should have been 'warning signs' of trouble." ${ }^{20} \mathrm{~A}$ federal investigation has turned up five other problems on the rig, including repeated losses of power and the malfunctioning of a key computer used to monitor drilling operations. ${ }^{21}$ All five of the problems had a common link in that they involved "bad decisions, missed warnings and worker disagreements. ${ }^{, 22}$

The severity of the incident was initially unclear. As the days passed, and it became more obvious that a major spill was underway, BP CEO Tony Hayward flew to the Gulf of Mexico to inspect the damage. $^{23}$ In the immediate aftermath of the explosion, BP estimated that approximately 1000 barrels of oil were leaking into the Gulf of Mexico per day. BP's initial estimates of the cost of cleanup, while still high, numbered in the low hundreds of millions of dollars. ${ }^{24}$ In fact, CEO Hayward further declared that the magnitude of the spill was "modest" compared to the size of the ocean. ${ }^{25}$ With hindsight, it now appears that everyone - from BP to the Coast Guard to the

riskier, since they advocated using only one pipe instead of two. Two pipes would provide an extra layer of protection. However, using one pipe was "easier and faster, likely taking a week less time than the two-pipe method." Id.

18. Juliet Eilperin, U.S. Exempted BP Rigs from Impact Analysis, WASH. Post, May 5,2010 , at A4.

19. Ian Urbina, BP Officials Took a Riskier Option for Well Casing, N.Y. TIMES, May 27, 2010, at A1.

20. Russell Gold \& Neil King Jr., BP Ignored Signs of Danger in Well, WaLl St. J., May 13, 2010, at A6; Steven Mufson, BP'S Investigation Finds Unheeded 'Warning Signs,' WASH. Post, May 26, 2010, at A7; Stephen Power, BP Cites Crucial 'Mistake'- 'Very Large Abnormality' in the Well Wasn't Heeded Hours Before Fatal Explosion, WALL ST. J., May 26, 2010, at A1.

21. Ben Casselman, Susan Daker \& Angel Gonzales, BP Weighs New Way To Plug the Well, WALL ST. J., July 20, 2010, at A6.

22. Russell Gold, Rig's Final Hours Probed, WALl ST. J., July 19, 2010, at A1.

23. In retrospect, Hayward's comments seem almost hubristic. He dismissed comparisons with the Exxon Valdez spill, noting, "The issue with the Valdez is that it took a long time to get the resources in place .... We've got enormous resources in place, and we're hitting it with everything we've got." Guy Chazan, BP's Escalating Costs Put Investors on Edge, WALL ST. J., May 1-2, 2010, at A4.

24. Clifford Krauss, Oil Spill's Blow to BP's Image May Eclipse Out-of-Pocket Costs, N.Y. TIMES, Apr. 30, 2010, at B1 (providing estimate from BP that the cost of the cleanup would only be several hundred million dollars).

25. Steven Pearlstein, For All Its Blunders, BP Didn't Cut and Run, WASH. Post, May 28, 2010, at A18. 
mainstream news media-underestimated the extent of the spill. ${ }^{26}$ Some accused BP of deliberately obfuscating the extent of the spill and interfering with scientists who were trying to estimate the extent of the damage. ${ }^{27}$

As the estimates of leaking oil were steadily revised upwardfrom 5000 barrels a day to 20,000 barrels a day to the alarming figures of 40,000 to 60,000 barrels a day-public pressure mounted to stanch the flow before marine life was damaged and the Gulf coastline was irretrievably despoiled. ${ }^{28}$ Building a relief well was estimated to take three months, which meant that the oil would continue to spill through the entire summer. ${ }^{29}$ In the meantime, BP tried a containment dome; ${ }^{30}$

26. Campbell Robertson \& Eric Lipton, Government Criticizes BP for Response to Oil Spill, N.Y. Times, May 1, 2010, at A1 ("Rear Adm. Mary E. Landry, the chief Coast Guard official in charge of the response, said on April 22, after the rig sank, that the oil that was on the surface appeared to be merely residual oil from the fire, though she said it was unclear what was going on underwater. The day after, officials said that it appeared the well's blowout preventer had kicked in and that there did not seem to be any oil leaking from the well, though they cautioned it was not a guarantee."); Julia Werdigier, Rising Oil Price Benefits BP Earnings, N.Y. TIMES, Apr. 28, 2010, at A16 ("[T] he accident is unlikely to hurt BP's production because the deposit at the rig was relatively small.").

27. A blog post by author John Robb recently explored this hypothesis. John Robb, No More Katrinas?, GlOBAL GuERRILlas (May 30, 2010, 6:26 AM), http://globalguerrillas. typepad.com/globalguerrillas/2010/05/journal-no-more-katrinas.html.

28. The amount spilled is vitally important because criminal penalties for the pollution are calculated per barrel. See Sam Dolnick \& Liz Robins, BP Says One Oil Leak of Three Is Shut Off, N.Y. TIMES, May 5, 2010, http://www.nytimes.com/2010/05/06/us/ 06spill.html ("[A] senior BP executive conceded ... that the ruptured oil well could conceivably spill as much as 60,000 barrels a day of oil, more than 10 times the estimate of the current flow."); Stephen Power, John Kell \& Siobhan Hughes, BP, Oil Industry Take Fire at Hearing: Scientists Raise Estimate of Leak to Up to 60,000 Barrels a Day, Raising Fresh Questions About Containment Plans, WALL St. J., June 16, 2010, at A5; see also Joel Achenbach, 5,000 or 26,000 Barrels a Day: Size of Spill a Guesstimate, WASH. Post, May 14, 2010, at A6 (noting that at first BP did not want to measure the extent of the spill); David A. Fahrenthold \& Joel Achenbach, Heavy Oil Reaches La. Marshland, WASH. Post, May 19, 2010, at A4 ("Officials had first estimated the leak at 5,000 barrels a day, but outside experts have said it appears much larger than that."); Kimberly Kindy, BP Falling Far Short of Claims on Oil Removal, WASH. Post, July 6, 2010, at A1 ("In late May, a group of scientists charged by the government with estimating the flow said the rate was 12,000 to 25,000 barrels a day. And in June, the official estimated rate jumped to 35,000 to 60,000 barrels a day."); Steven Mufson \& David Fahrenthold, Federal Officials Say Oil Is Gushing Faster than Thought, WASH. Post, May 21, 2010, at A6 ("One month after the start of a massive oil spill in the Gulf of Mexico, federal officials said ... that oil was gushing out of the ground faster than they had estimated - and that it would be days before they had a firm handle on the rate.").

29. Ben Casselman, Stephen Power \& Ana Campoy, Oil-Spill Fight Bogs Down, WALl St. J., May 1-2, 2010, at A1.

30. Steven Mufson \& Mark Kaufman, Oil Spill Gushes on Amid Technical Problems, WASH. Post, May 9, 2010, at A5 (reporting failure of containment dome due to the formation of ice-like crystals); Ian Urbina, Justin Gillis \& Clifford Krauss, On Defensive, BP Tests Ideas To Stem Leaks, N.Y. TIMES, May 4, 2010, at A1. 
a capping device imaginatively named a "top hat"; a "top kill" maneuver, using liquids to push the oil back down the well; ${ }^{32}$ a junk shot, which tried to plug the hole with smaller material, ${ }^{33}$ and a tube to capture the oil. ${ }^{34}$ Unfortunately, these efforts either failed completely or made little impact. ${ }^{35}$

As BP's repeated attempts to stop the spill failed, local, state, and federal officials found themselves under increasing pressure from the public. $^{36}$ It was unclear, however, what the government could do, since BP had the on-ground engineering expertise and was also providing the funding for the operations. ${ }^{37}$ As days turned into weeks, the Obama administration came under fire for mishandling the spill, and President Obama changed his tone from one of cooperation to one that was increasingly bellicose, capped by his comment that he was not studying the problem out of a detached academic interest, but rather because he needed to know "whose ass to kick." 38 Meanwhile, Hayward had to admit that BP should have been more prepared for such an emergency, admitting that "[i]t's clear that we will find things we can do differently, capability that we could have available to deploy instantly, rather than be creating it as we go."39

31. Brian Baskin, BP Tries Again To Halt Spewing Oil, Wall ST. J., May 13, 2010, at A6 (describing the containment box known as a "top hat"); Henry Fountain \& Matthew L. Wald, BP Says Leak May Be Closer to a Solution, N.Y. TIMES, May 13, 2010, at A1 (same).

32. Clifford Krauss \& John M. Broder, After Delay, BP Resumes Effort To Plug Oil Leak, N.Y. TIMES, May 28, 2010, at A1.

33. Clifford Krauss \& Jackie Calmes, Little Headway as BP Struggles To Halt Oil Leak, N.Y. TIMES, May 29, 2010, at A1.

34. Joel Achenbach \& Juliet Eilperin, BP Fails in Its Latest Attempt To Contain Oil, WASH. Post, May 16, 2010, at A6.

35. Leslie Kaufman \& Clifford Krauss, BP Says Its Latest Effort To Stop Gulf Leak Failed, N.Y. Times, May 30, 2010, at A1.

36. Karen Tumulty \& Steven Mufson, Administration Torn on Getting Tough with $B P$, WASH. Post, May 25, 2010, at A1.

37. Juliet Eilperin, Crisis Forces Government, BP To Work Together, WASH. Post, May 14, 2010, at A6; Jonathan Weisman \& Jeffrey Ball, U.S. Turns Up Heat on BP, WALL ST. J., May 25, 2010, at A1 ("While some critics have asked why the White House doesn't take control of the cleanup, Coast Guard Admiral Thad Allen, speaking at the White House Monday, said he wouldn't recommend it. He said the government doesn't have more technology or expertise than the oil giant to deal with the leaking well, anyway.").

38. Justin Gillis \& Henry Fountain, Rate of Oil Leak, Still Not Clear, Puts Doubt on $B P$, N.Y. TIMES, June 8, 2010, at A1 (“'I don't sit around just talking to experts because this is a college seminar' ... ' 'We talk to these folks because they potentially have the best answer so I know whose ass to kick."” (quoting President Obama)); see also Michael Cooper, Obama Warns BP on Paying Big Dividends Amid Oil Spill, N.Y. TIMES, June 4, 2010, available at http://www.nytimes.com/2010/06/05/us/politics/05obama.html (noting tough talk from President Obama).

39. Guy Chazan \& Jim Carlton, BP Wasn't Prepared for Leak, CEO Says, WALL ST. J., May 14, 2010, at A5 (internal quotation marks omitted). 
Government officials were especially concerned with who would pay for the cleanup, and were alarmed at the prospect that the taxpayers might find themselves saddled with that responsibility. The news media buzzed with discussion of BP's attempt to shift liability onto Transocean and concern that there might not be enough money available for a thorough cleanup. ${ }^{40}$ Under a law passed in the aftermath of the Exxon Valdez disaster, liability for oil spills was limited to a mere $\$ 75$ million, plus cleanup costs, which seemed woefully inadequate. ${ }^{41}$ That liability limitation, however, would not apply if there was "gross negligence" or criminal action, which could result in the imposition of high fines. ${ }^{42} \mathrm{BP}$ was criticized for not doing enough to stop the continuing spill, and Hayward fanned the flames of resentment with his statement that he would "like his life back." ${ }^{, 4}$

In the middle of June, the government and BP announced that a settlement — outside the typical legal processes - had been reached. ${ }^{44}$ BP agreed to pay $\$ 20$ billion to a general-purpose fund that would cover costs of the cleanup and provide reimbursement to those Gulf residents whose lives had been affected. ${ }^{45}$ While claimants could opt out of the claims process and file in court, the fund promised to be a more efficient and ready route to obtain payment. Those who were making claims would not hire attorneys, which cut down on

40. Thomas Catan \& Dionne Searcey, Dispute Rages on BP Liability for Wages, as Obama Pushes, Wall ST. J., June 11, 2010, at A6; Guy Chazan \& Stephen Power, U.S. Ramps Up Tab on BP-Stock Plunges as White House Insists Company Pay All Idled Oil Workers in Gulf, WALL ST. J., June 10, 2010, at A1.

41. Oil Pollution Act of 1990, 33 U.S.C. $\S \S 2701-2761$ (2006); see also William W. Enders, The Oil Pollution Act of 1990: The Financial Responsibility RequirementQuestioning Congressional Intent and the Minerals Management Service Interpretation of “Offshore Facility," 14 VA. ENVTL. L.J. 455, 460-61 (1995); Neil King Jr. \& Guy Chazan, Effort To Raise BP's Liability Cap Gains Momentum, WALL ST. J., May 6, 2010, at A5.

42. Steven Mufson \& Theresa Vargas, As Outcry Grows, Investors Batter BP, WAsH. Post, June 2, 2010, at A1.

43. Jad Mouawad \& Clifford Krauss, Another Torrent BP Works To Stem: Its C.E.O., N.Y. TIMES, June 4, 2010, at A1; Eugene Robinson, At BP, Firing Offenses, Wash. PosT, June 4, 2010, at A19. Hayward later infuriated the public further when it was revealed that he had taken time off to watch his yacht compete in a race around England's waters. BP's Hayward Blasted for Taking in Yacht Race, WASH. PosT, June 20, 2010, at A2; Liz Robbins, Embattled BP Chief Takes in Yacht Race, N.Y. TIMES, June 20, 2010, at A20.

44. Jonathan Weisman \& Guy Chazan, BP Agrees to \$20 Billion Fund, WaLl ST. J., June 17, 2010, at A1.

45. Steven Mufson, BP Details Plan for \$20 Billion Claim Fund, WASH. Post, June 17, 2010, at A8. To pay for the fund, BP is selling oil and gas assets, cutting spending, and suspending a planned dividend. Guy Chazan \& Gina Chon, BP Sells \$7 Billion of Assets To Help Fund Cleanup, WALL ST. J., July 21, 2010, at A7. 
transaction costs. ${ }^{46}$ Kenneth Feinberg - who previously administered the September 11th fund to assist those affected by the terrorist attacks on the World Trade Center and also served as Obama's "Pay Czar" overseeing executive compensation at the companies that received TARP government bailout money - was named the head of the relief fund. ${ }^{47}$

On July 15, 2010, eighty-five days after the Deepwater Horizon explosion, BP announced that it had found a temporary solution in a tightly fitted cap, which successfully contained the leaking oil. ${ }^{48}$ During the spill, Gulf residents continuously lamented the lack of skimmers available to collect the oil before it reached shore. Thousands whose livelihood depended on tourism or on harvesting marine life remain unemployed. ${ }^{49}$ Hurricane Katrina had already scarred the area, and the oil spill struck a second devastating economic blow. No one is sure of the extent of the environmental damage, or how long it will take to clean the area of the spilled oil. ${ }^{50}$ The federal government officially declared the Macondo well "dead" on September 21, 2010. It may be years, if not decades, before the damage is remediated. ${ }^{51}$

46. The claims process, however, still has some contentious debates. For example, a number of fishermen are frustrated that any money they make skimming oil in the cleanup efforts is being subtracted from the amount of their claim against the settlement fund. Under that type of process, it actually is more economically efficient for a vessel to sit idle than to participate in the cleanup effort. See Matthew Bigg, Gulf Coast Fishermen Angry over Oil Claims Ruling, REUTERS, July 17, 2010, http://www.reuters.com/article/idUSTRE66F 64J20100717.

47. Ed O'Keefe, Obama's 'Pay Czar' To Oversee BP Victims' Fund, WASH. Post, June 17, 2010, at A19; Scott Wilson \& Joel Achenbach, BP Agrees to \$20 Billion Fund for Gulf Claims, WASH. Post, June 17, 2010, at A1. Of course, criminal fines and other costs associated with the spill could amount to far more than the amount in the fund, and as there was no absolution from that liability, BP presumably will have to pay more than the amount that was put into escrow. John Schwartz, Costs to BP Would Soar Under Criminal Charges, N.Y. TIMES, June 17, 2010, at A18 (estimating BP's liability to be $\$ 62.9$ billion in total).

48. Susan Daker \& Russell Gold, Oil Spill Halts, for Now, as BP Tests Out New Cap, WALl ST. J., July 16, 2010, at A1. However, there is a continuing concern that the oil might begin leaking again from the sides, as the cap is only a temporary measure. Casselman, Daker \& Gonzales, supra note 21, at A6.

49. Russell Adams \& Justin Lahart, Locals Grapple with Road to Recovery, WALL ST. J., July 19, 2010, at A4.

50. Jeffrey Ball, Early Look at Ecological Toll Is Alarming, Scientists Say, WALL ST. J., July 19, 2010, at A4.

51. A recent article asked many difficult questions left in the aftermath of the spill. Allen G. Breed \& Vicki Smith, Residents Struggle with Work Options, Associated PrESS, July 19, 2010, available at http://www.2theadvocate.com/news/98721704.html?c= 1288239023809 ("Which species will rebound, and which have been pushed beyond the brink? Has the oil accelerated the die-off of marshlands that protect one of America's great cities and make this the nation's second-most-productive fishing region?"). 


\section{B. Safety Violations}

Long before the Deepwater Horizon explosion, BP had a troubling record of noncompliance with environmental regulations and worker safety. Iain Conn, BP's head of refining and marketing, admitted in a recent interview that the company had "a lot to prove .... A bad track record leaves you with a long shadow, and we have to deal with that." ${ }^{32}$ Others in the industry noticed that after its strategic acquisitions in the beginning of the last decade, costs were cut by firing the engineers with the most experience, which perhaps was not the best decision from a safety perspective. ${ }^{53}$ When Hayward took the helm as CEO, he noted that he would make safety the first priority of the company and would focus on it like a "laser."."54 The record reflects, however, that there were numerous safety problems after the shift to Hayward's leadership and ostensible commitment to safety concerns. ${ }^{55}$

Although Hayward said he was committed to creating a new system of safety standards, it was impeded due to a "shortage of experienced offshore workers" and a lack of training to "maintain safe, reliable and efficient operations." ${ }^{156}$ According to an internal BP report in 2007, which detailed ten near-miss incidents in the Gulf of Mexico, a "common theme ... was a failure to follow BP's own procedures and an unwillingness to stop work when something was wrong.".57 Further, in 2007 alone, BP paid \$373 million in settling lawsuits that arose from the Texas City refinery explosion, oil spills along BP's pipeline in Alaska, and the allegation that BP traders were manipulating the market for propane. ${ }^{58}$ We will discuss the various safety problems at BP as they arose chronologically, to show how BP's reality was far different from the green myth they sought to convey.

In 2002, California officials brought a lawsuit - which eventually settled for \$100 million — alleging that BP falsified inspection reports

52. Guy Chazan, BP Already in Safety Spotlight, WALl ST. J., Apr. 22, 2010, at A4 (internal quotation marks omitted).

53. Joe Nocera, BP Ignored the Omens of Disaster, N.Y. TIMES, June 19, 2010, at B1 ("Taking shortcuts was ingrained in the company's culture, and everyone in the oil business knew it.”).

54. Guy Chazan, Benoit Faucon \& Ben Casselman, Safety and Cost Drives Clashed as CEO Hayward Remade BP, WALL ST. J., June 30, 2010, at A1.

55. Id. (“" $[\mathrm{T}]$ hey $[\mathrm{BP}]$ claim to be very much focused on safety, I think sincerely. ... But somehow their sincerity and their programs don't always get translated well into the refinery floor."' (quoting OSHA inspector)).

56. Id. (internal quotation marks omitted).

57. Id.

58. Id. 
of fuel tanks at a refinery located in Los Angeles. ${ }^{59}$ Other problems with refineries had much more dire consequences for workers. A 2005 explosion at a refinery in Texas City, Texas, led to the death of fifteen workers and the injury of hundreds more. ${ }^{60}$ OSHA fined BP $\$ 87$ million for noncompliance with safety regulations arising from the Texas City explosion. An investigation after the accident found that the routine maintenance that was necessary - and which would have prevented the accident-had not been performed because it was deemed too expensive. ${ }^{61}$ Criminal charges against BP were later settled for $\$ 370$ million in fines, with a statement by BP that its operations "failed to meet [BP's] own standards and the requirements of the law." ${ }^{92}$ Also in 2005, Thunder Horse, one of BP's developments in the Gulf of Mexico, severely listed after a hurricane. Investigators, however, concluded - rather alarmingly - that this was the result of engineering problems and not the hurricane per se. ${ }^{63}$

In 2006, OSHA inspected a BP refinery in Toledo, Ohio, and found problems with pressure relief valves, which they instructed BP to remediate. ${ }^{64}$ When inspectors returned two years later, they found that the specific valves that had been noted in the report had been replaced, but not the same type of noncomplying valves that were located in other areas of the refinery. ${ }^{65}$ OSHA fined BP \$3 million and ordered BP to fix all the remaining valves. ${ }^{66}$ While BP was perhaps meeting the letter of compliance, it was certainly not following the spirit of compliance.

Also in 2006, it was discovered that a portion of BP's Alaska pipeline near Prudhoe Bay had repeatedly been leaking oil into the tundra due to pipe corrosion. ${ }^{67}$ Despite later replacement of certain pipes and installation of a leak detection system, the spills continued. In a court filing, the State of Alaska accused BP of "poor maintenance

59. Abrahm Lustgarten \& Ryan Knutson, BP Had a History of Problems - Internal Inquiries Show Firm Continued To Ignore Safety, Environmental Rules, WASH. Post, June 8, 2010, at A1.

60. The workers apparently were contractors, not BP employees, but the company paid compensation to them regardless of status. Tom Bower, Drilling Down: A Troubled Legacy in Oil, WALL ST. J., May 1-2, 2010, at W3; Krauss, supra note 24.

61. Jad Mouawad, Fast-Growing BP Also Has a Mounting List of Spills and Safety Lapses, N.Y. TIMES, May 9, 2010, at A22.

62. Id. (internal quotation marks omitted).

63. Bower, supra note 60.

64. Chazan et al., supra note 54.

65. Id.

66. Id.

67. Bower, supra note 60. 
practices" and alleged that a failure to maintain the pipeline properly had resulted in several recent spills. ${ }^{68}$ There had also been a rupture on a portion of a natural gas pipeline operated by BP, which could have resulted in a major disaster. Apparently BP had not inspected or maintained the pipeline for over a decade before the rupture. ${ }^{69}$

An internal inquiry at BP after the Alaska spill came to some alarming conclusions. The internal investigation found that the company had a "pattern of . . intimidating workers who raised safety or environmental concerns. It said managers shaved maintenance costs by using aging equipment for as long as possible., ${ }^{, 70}$ The report also "quoted an employee who said employees felt forced to skip key diagnostics, including pressure testing, pipeline cleaning and corrosion checks." ${ }^{\text {"71 }}$ The same news story also detailed the tale of one whistleblower who was summarily fired for expressing safety concerns when he attempted to report hazardous conditions on the pipelineconditions that could well have led to an explosion. ${ }^{72}$

On June 5, 2008, Atlantis Oil Platform, located in the Gulf of Mexico, suffered a ruptured piece of steel tubing. The tubing was "attached to a defective pipeline pump that BP had put off repairing, in what an internal report later described as 'the context of a tight cost budget.","73 While only 193 barrels of oil were spilled, which certainly seems minor compared to the Deepwater Horizon disaster, the fact is that consistent delayed maintenance signaled a critical weakness in BP's operations. One reporter noted that "[a]s investigators were questioning Atlantis' lean operation, top executives were praising it." ${ }^{\text {,74 }}$ In fact, according to an internal communication in 2009, Neil Shaw, who was head of BP's Gulf of Mexico operations, "lauded Atlantis' operating efficiency, saying it was ' $4 \%$ better than plan' in its first year of production." ${ }^{975}$ Although no major incidents had been reported in the Gulf, it seemed like it was only a matter of time before there was an incident. According to an internal BP presentation, there were ten near

68. Chazan et al., supra note 54

69. Id.

70. Lustgarten \& Knutson, supra note 59 (noting that the internal report, compiled with the assistance of the law firm Vinson \& Elkins, contained a "harsh assessment of BP's management of employee concerns" and that "[a]ccording to the report, workers accused the company of allowing 'pencil whipping,' or falsifying inspection data").

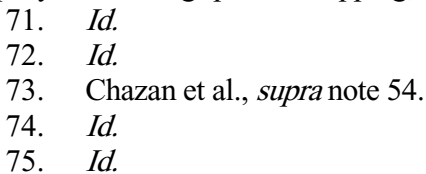


misses in 2007 alone, and one in which a worker suffered an electric shock. $^{76}$

In 2009, a repeat OSHA inspection back at the Texas City refinery unearthed even more troubling facts. Safety violations, much like the ones that led to the 2005 explosion, abounded in the refinery. OSHA imposed the largest fine in the agency's history, \$87 million, much of which was for "failure to abate" the problems that had caused the previous explosion. ${ }^{77}$ A former employee, Ross MacFarlane, who was the health and safety manager on several BP rigs, claims that employees had "high incentive to find shortcuts and take risks .... You only ever got questioned about why you couldn't spend lessnever more." ${ }^{78}$

Later reports and investigations confirmed that numerous shortcuts were taken regarding the exploration of the Macondo oil field where the Deepwater Horizon rig was drilling. Not only was the riskier type of single well casing used, but an email that was sent by an engineer only four days before the explosion noted that "engineers had not taken all the usual steps to center the steel pipe in the drill hole, a standard procedure designed to ensure that the pipe would be properly cemented in place. '[W]ho cares, it's done, end of story, will probably be fine and we'll get a good cement job."' 99 Fewer devices were used to center the drill pipe in the well than the subcontractor, Halliburton, had recommended. The recommended centralizers were not on-site, and it would have taken an additional ten hours to install them. ${ }^{80}$ In addition, BP did not circulate mud through the well before starting the cement fill - a technique recommended by the trade group, the American Petroleum Institute - or attempt a cement bond log, which would have tested the quality of the cement barrier. ${ }^{81}$ Some of the decisions violated industry standards and seemed to be taken even when there were warnings either from BP employees or subcontractors. $^{82}$ The congressional report details many other

\footnotetext{
76. Id.

77. Id.

78. Id. (internal quotation marks omitted).

79. Steven Mufson \& Anne E. Kornblut, Lawmakers Accuse BP of "Shortcuts," WASH. Post, June 15, 2010, at A1.

80. Id.

81. Henry Fountain, Documents Show Risky Decisions Before BP Blowout, N.Y. TIMES, June 14, 2010, http://www.nytimes.com/2010/06/15/science/earth/15rig.html.

82. Id.
} 
instances in which BP compromised safety in the name of cost savings. $^{83}$

From this factual account, we turn next to examining BP's advertising and branding campaign, juxtaposing BP's green myth with the factual reality we have just explored.

\section{The Myth: BP’s History AND “Beyond Petroleum” INITIATIVE}

In the aftermath of the Deepwater Horizon tragedy, many of BP's previous safety errors came to the public's attention. However, over the years, many of these safety issues were largely ignored; instead, BP had covered these safety problems by cultivating an image as a leader in CSR, a role that they spent $\$ 200$ million in advertising to promote. We begin this Part by examining the history of the company, then turn to its "Beyond Petroleum" advertising campaign, and the timeline of how BP attempted to green its image in the earlier part of the decade. Finally, we end this Part by discussing the just-released memoirs of BP's most recent former CEO, Lord John Browne, who led the effort to green the company's image.

\section{A. History, Cast of Characters, and Corporate Culture}

Originally known as the Anglo-Persian Oil Company, BP struck oil in 1908 in the area then known as Persia (modern day Iran). ${ }^{84}$ In the years immediately following the discovery, however, BP struggled, because there was difficulty finding a market for its products. ${ }^{85}$ At that time, automobiles were only a luxury product and the demand for oil, which was mostly put to industrial use, was largely met by small local producers.

The mass production of automobiles, the invention of the airplane, and the mobilization of troops during World War I, however, all led to a surge in the demand for oil. While the British government did provide some investment capital to the company, the "BP" label actually came from a World War I nationalization of a German company that had used the name to distribute oil in the United

83. Id.; Mufson \& Kornblut, supra note 79.

84. This background historical information is taken largely from the official BP company Web site. First Oil, BP, http://www.bp.com/sectiongenericarticle.do?categoryId= 9014440\&contentId=7027520 (last visited Feb. 27, 2011).

85. Early History, BP, http://www.bp.com/sectiongenericarticle.do?categoryld= 9014441\&contentId=7027521 (last visited Feb. 27, 2011). 
Kingdom. ${ }^{86}$ During World War II, oil reserves once again played a vital strategic role in the conflict. With the postwar British Empire crumbling, the company found itself pushed out of Persia. ${ }^{87}$ In 1954, the company officially changed its name to "The British Petroleum Company." The company, along with others, was eventually allowed to continue its extraction efforts in Iran. ${ }^{88}$ In subsequent years, BP made several major finds in different areas of the world, including Prudhoe Bay, Alaska. ${ }^{89}$

As Middle Eastern nations began nationalizing their oil fields, BP increasingly turned to offshore drilling in the United Kingdom and in Alaska. In the 1970s, BP found itself in conflict with environmentalists regarding its Alaska pipeline. In its official company history reprinted on its website, BP credits the Alaska pipeline battle as a lesson learned: "From the protracted Alaskan debate BP took away a lesson about the value of dealing with potentially contentious environmental considerations at the very start of major projects. More importantly BP found within itself a passion for confronting environmental challenges with ingenuity and determination.".90

In the late 1990s, then-CEO Lord John Browne was one of the first major oil company executives to acknowledge the existence of global climate change. He also approved of the "Beyond Petroleum" advertising campaign. ${ }^{91}$ In essence, the idea was to market BP as an energy company that cared about finding renewable sources of power, not just the old-fashioned ways that "big oil" had operated in the past. During his tenure at BP, Lord Browne engaged in a series of strategic acquisitions. BP purchased Amoco, a major player in American markets. While the acquisition greatly expanded BP's scope and reach as a company, observers questioned how successfully BP was able to integrate the former Amoco operations and personnel into its organization. Others questioned whether staff redundancies resulted in

86. Id.

87. Post War, BP, http://www.bp.com/sectiongenericarticle.do?categoryld=9014443 \&contentId=7027523 (last visited Feb. 27, 2011).

88. Id.

89. Id.

90. Late Century, BP, http://www.bp.com/sectiongenericarticle.do?categoryId= 9014444\&contentId=7027525 (last visited Feb. 27, 2011).

91. See Krauss, supra note 24 ("Under Mr. Hayward's predecessor, John Browne, BP rebranded itself as 'Beyond Petroleum,' a company that was environmentally conscious and wanted to develop alternative energy sources like solar and wind power. Its insignia of a blooming flower was intended to portray the company as one that was responsive to growing public concerns about climate change."). 
lower safety standards. ${ }^{92}$ The last few years of Browne's tenure were problematic due to an explosion at the Texas City refinery, discussed below. With his reputation already damaged by the Texas City refinery explosion, Browne was vulnerable, and other safety issues were on the horizon. Although some dispute the reasons for his ouster, Lord Browne described his decision to resign as a response to a scandal about his personal life. ${ }^{93}$

Browne's successor, Tony Hayward, backed off the "Beyond Petroleum" campaign, noting that BP's core business was the extraction and distribution of oil. ${ }^{94}$ Trained as an engineer and geologist, Hayward had a "back to fundamentals" approach. At the time, Hayward said, "The bit about 'beyond petroleum' being dead and buried is nonsense .... [I]t's a business as opposed to an advertising slogan. ${ }^{95}$ Although Hayward's quote is rather enigmatic, it showcases the problematic relationship between the advertising campaign and BP's corporate culture. Further, Hayward led a cost-cutting drive that some argue "allowed the company to put more resources into operations, including safety. Yet critics have asked whether the aggressive internal trimming also nurtured a culture of cutting corners. ${ }^{.96}$ During the crisis, Hayward came under attack for various gaffes, including the infamous comment that he would "like [his] life back" and his taking time off to attend a yacht race as the catastrophe in the Gulf continued to unfold. ${ }^{97}$ He also raised the ire of members of Congress when he seemed to evade their questions, and President Obama made it clear that if it were up to him, he would have fired Hayward long before for those mistakes. At the end of July, the BP board announced that it was replacing Hayward with Robert Dudley, a U.S. citizen who spent his childhood in the Gulf region. ${ }^{98}$

92. Guy Chazan, BP’s Worsening Spill Crisis Undermines CEO’s Reforms, WALL ST. J., May 3, 2010, at A1; Nocera, supra note 53.

93. Browne chose to keep his sexuality private, but a former boyfriend blackmailed him and then outed him by selling his story to tabloids. Browne lied about the affair in an attempt to protect his privacy. JOHN BROWNE WITH PHILIPPA ANDERSON, BEYOND BusINESS 215-25 (2010).

94. In recent years, BP was involved in more political lobbying, something that came as a disappointment to the Sierra Club. Dan Eggen, BP Is Getting More Political, WASH. Post, May 6, 2010, at A17.

95. Steven Mufson, BP Chief Executive Grappling with Crises on Several Fronts, WASH. Post, May 3, 2010, at A6 (internal quotation marks omitted).

96. Paul Sonne, In Crisis, Hayward Struggled To Find Right Tone, Wall St. J., July 26, 2010, at A7.

97. See sources cited supra note 43.

98. Bruce Orwall, Monica Langley \& James Herron, Embattled BP Chief To Exit, WALl St. J., July 26, 2010, at A1; Harry R. Weber, Official: BP CEO Hayward Being 


\section{B. The "Beyond Petroleum" Advertising Campaign}

During the past decade, BP made a series of strategic branding decisions designed to green the company's image. First was a play on their acronym "BP," claiming that their initials stood for "Beyond Petroleum." The next group of advertisements suggested that BP was aware of various environmental issues and was willing not only to discuss them but also to start taking action. Using the tagline "It's a Start," the advertisements noted that BP was making their operations more efficient and reducing overall carbon emissions in extracting petroleum. ${ }^{100}$ Further, they acknowledged the issues of global climate change and advocated that each person be aware of his or her "carbon footprint.",

Other advertisements touted BP's use of and investment in renewable sources of energy such as biofuels, wind, and solar energy. ${ }^{102}$ In order to be successful long-term, the advertisements stated, an energy company would need to diversify the sources from which that energy came. ${ }^{103}$ The advertisements featured "man on the street" type interviews that asked average people what their thoughts were about global warming and other hot-button environmental issues.

Other strategic choices included the construction of the Helios House, an environmentally friendly gas station in Los Angeles, California. ${ }^{104}$ Helios House gas station featured solar panels on the roof, an ultramodern bathroom that was water efficient, and an abundance of plants to absorb carbon. BP Magazine noted the fact

Replaced, AssOcIATED PRESS, July 25, 2010, available at http://www.washington times.com/news/2010/jul/25/official-bp-ceo-hayward-being-replaced-over-spill/.

99. BP, Beyond Oil, YouTuBE (Sept. 15, 2006), http://www.youtube.com/watch? $\mathrm{v}=8$ liOnfr2BjY. BP also stands for Brown Pelican, the Louisiana state bird often photographed covered in oil in news accounts of the spill's environmental damage.

100. BP, New Sources of Energy, YouTuBE (Oct. 8, 2006), http://www.youtube.com/ watch? $\mathrm{v}=\mathrm{p} 9 \mathrm{~m} 7 \mathrm{jo} 5 \mathrm{I} 1 \mathrm{GQ}$.

101. BP, Global Climate Change, YouTuBE (Oct. 8, 2006), http://www.youtube.com/ watch?v=IZiEMKQMjzg; BP, Carbon Footprint, YouTuBE (Dec. 10, 2008), http://www. youtube.com/watch?v=ywrZPypqSB4; see also BP, Carbon Footprint-What Is It? YOUTUBE (Jan. 15, 2007), http://www.youtube.com/watch?v=fk-oxSfAuOA.

102. BP, British Petroleum, YouTuBE (Apr. 29, 2009), http://www.youtube.com/ watch?v=thXeYv-Zxr4; BP, BP Commercial, YouTuBE (Jan. 4, 2009), http://www.youtube. $\mathrm{com} /$ watch? $\mathrm{v}=\mathrm{RrDiRgRuPMQ}$.

103. Alternative Energy, BP, http://www.bp.com/sectiongenericarticle.do?categoryId= 9018233\&contentId=7033043 (last visited Feb. 27, 2011).

104. A description of Helios House appears in a magazine that BP published to showcase its new advertising campaign and its stance toward innovation and environmental causes. Lucy Harvey, Innovation on the Front Line, BP MAG., 2:2007, http://www.bp.com/ liveassets/bp_internet/globalbp/globalbp_uk_english/reports_and_publications/bp_magazine/ STAGING/local_assets/pdf/bp_mag_issue_2_2007_retail_therapy.pdf. 
that the gas station saved twenty percent of the power that the average gas station-convenience store combination would use. ${ }^{105}$ Anecdotal evidence suggests that many in Los Angeles were impressed with the Helios House and went out of their way to use the station as opposed to others because they liked the environmentally friendly message as well as the ultra-modern, green construction. ${ }^{106}$ Other environmentalists - before the Gulf oil spill, of course - had recommended stopping to fill up at BP because of their reputation as a greener company. ${ }^{107}$

According to $B P$ Magazine, company executives were hoping that the advertising campaign would have exactly that effect - that it would cause customers to go out of their way-or at least a block or two out of their way - to fuel their cars at a BP station. It was a method of branding what was otherwise a highly price-dependent, fungible commodity. ${ }^{108}$ As Ann Hand, BP's marketing chief, put it:

With Helios House, we wanted to challenge the image of buying gasoline and see if our consumer brand could drive more shareholder value .... Since it opened, the site has nearly doubled its fuel volumes, compared with its predecessor and it's selling six times as much premium fuel.... Consumers these days want it all, and their interest in the environment is at an all-time peak. It is a perfect time for our unique brand to offer them a better guest experience and reinforce our values on the environment, climate change and sustainability. We have a shareholder obligation to maximise value and increase sales revenue, but, at the same time, we can deliver great guest experience and build brand loyalty. That creates a win-win situation for our consumers and our shareholders. ${ }^{109}$

Hand's explanation, taken directly from BP Magazine, describes the corporate philosophy at the time. Or, as a recent Wall Street Journal article put it, BP had spent "hundreds of millions of dollars to build its image over the years using slogans such as 'Beyond Petroleum,' as it

105. Id.

106. Telephone Interview with Anne Bloom, Visiting Professor of Law, Loyola Law School Los Angeles (July 10, 2010).

107. Brendan Borrell, Had Your Fill of BP?, WASH. Post, June 29, 2010, at E3 (noting that before the Deepwater Horizon spill, BP had been rated highly as an eco-friendly gas station choice).

108. Hart \& McGinn, supra note 4 (noting that BP once enjoyed "the halo created by a decade of smart advertising" that had "positioned the company on the green side of energy development").

109. Harvey, supra note 104, at 12 (internal quotation marks omitted). 
tried to position itself as the 'greenest' of the big oil companies." ${ }^{\text {"10 }}$ The strategy seemed to work, catapulting BP to the eighty-third largest company brand in the world. ${ }^{11}$

\section{Former BP CEO Lord John Browne's Memoir}

In recent years, numerous high-profile business executives have penned widely read autobiographical accounts. ${ }^{112}$ In these memoirs, former business leaders recount high-pressure deals and significant strategic choices while providing insight into the attitudes and work ethic that led to their successes. ${ }^{113}$ Much like the stories of historical, political, or spiritual leaders, executives' stories show that the individual may have a significant impact on the way that a particular type of collective social organization - in this instance, a businesscarries out its policies and goals.

Interestingly, Lord John Browne, who served as CEO of BP from June 10, 1995, to May 1, 2007, released a memoir about his tenure at the helm of BP mere months prior to the explosion of the Deepwater Horizon. ${ }^{114}$ In contrast to the recent negative publicity that has surrounded the company, Lord Browne's memoir is celebratory of BP's progress, both in the expansion of the business throughout the world, as well as in its environmental record. Organized around significant locations in his life, Browne's memoir recounts his father's career in the oil industry and details his own spectacular rise - as he terms it, his "adventure in oil" - through the corporate ranks, ultimately to become the head of the company. ${ }^{115}$

Discussing his years as CEO, Browne notes that BP was the first oil company to acknowledge the impact of global warming; Browne acknowledged the impact of carbon emissions during a speech he made at Stanford in 1997. ${ }^{116}$ At the time, the speech invited much derision from petroleum industry trade groups, but Browne notes that despite the criticism for taking a different line from the rest of big oil, he remained committed to the message that something needed to be

110. Suzanne Vranica, BP Steps Up Bid To Fix Image, Wall St. J., June 7, 2010, at B4.

111. Id.

112. See, e.g., LeE Iaccoca With William NovaK, IACCoca: An Autobiography (1984); JACK Welch \& JoHn A. BYRne, JACK: StRAight FrOM THE Gut (2001).

113. See sources cited supra note 112.

114. BROWNE, supra note 93, at 255-70 (providing chronology of Browne's tenure at BP).

115. Id. at 3 .

116. Id. at $83-84$ 
done about climate change. ${ }^{117}$ In his words, "I was the chief executive of an oil company and I was about to become an environmental activist. The message had to be clear and there had to be no doubt that BP was set on creating a new future." ${ }^{\prime 18}$ Lord Browne also describes BP's charitable contributions to environmental causes. He recounts his efforts to reduce carbon emissions in the extraction and refining of petroleum, and to investigate other forms of energy. ${ }^{119}$ Some of these efforts were innovative - for example, offering to plant trees to offset a large customer's carbon footprint rather than a more traditional gift to thank them for their patronage. ${ }^{120}$ Lord Browne also notes his efforts to increase employee diversity at $\mathrm{BP},{ }^{121}$ to invest in the various communities in which BP was extracting oil, and to employ local residents across the world. ${ }^{122} \mathrm{He}$ also notes his successes at achieving mergers with Amoco, Castol, and others, which turned BP from a fading dirty oil has-been to a global best-selling brand-a "supermajor"-a truly transnational company with a global brand.

By his own account, Lord Browne's business philosophy almost seems to have been ripped from a textbook on corporate social responsibility. Consider the following excerpt:

During all my time with BP, there was a debate on the wider purpose of

business.... Increasing short-term profits is often thought to be the

117. Id.

118. Id

119. Id. at 85-86 ("In little more than four years, we met our goal of reducing our greenhouse gas emissions by 10 per cent. This was achieved by reducing flaring and venting of natural gas and improving the energy efficiency of our operations. BP generated $\$ 650$ million of value. It was impressive. We had demonstrated that being environmentally friendly did not mean a trade-off with profitability, quite the opposite.").

120. Id.

121. Id. at 197 ("I decided BP had to take a leadership role in diversity and inclusion. First, we had to ensure that we used, in so far as we could, one definition of merit. That would allow us to level the playing field.... Second, we changed the way we recruited and developed people so that wherever we were in the world we were attracting the best onesboth women and men. In the past our selection panels had not been diverse; white males were likely to recruit and promote in their own image. Now we insisted on diverse memberships. We started to recruit in every country where we operated, not just to get local talent but to access an international cadre of people to run our business across the world.").

122. For example, Browne recounts a series of problems with BP's operations in Colombia, noting:

In Colombia we learnt that the issues of human rights, land ownership and environmental impact are not add-ons but integral elements which must be well managed to make the business sustainable over the longer term.... We now realized we had to ensure we considered social responsibility as an integral part of everyday business operations.

Id. at 102 . 
same as creating "shareholder value".... But I began to understand that this way of thinking erodes a commitment to the longer term. After all, shareholder value is not about returns and growth rates alone; it is also about how long a company can keep growing. ... A business must be useful to society and be seen as such. This approach to investment has commonly been called corporate social responsibility (CSR).

I firmly believe that a business needs a greater purpose than just making profits. CSR must be integrated into its daily thinking and activities over a sustained period. In BP's case that greater purpose became to fulfil basic human needs: to provide heat, light and mobility and to go beyond petroleum. ${ }^{123}$

Browne notes this same corporate philosophy at various other points in the memoir. For example, he states that BP "not only made good profits but also made the sustainable development of society, in every country in which it was active, an integral part of its strategy and dayto-day business." ${ }^{24}$ Not only was this philosophy the right way to operate, but according to Browne, it also provided instrumental benefits in the way of retaining employees. ${ }^{125}$

Browne also addresses the rebranding of the company as "Beyond Petroleum," noting that the new advertising was controversial. $^{126}$ As for the message that he meant to convey, Browne notes that the

new helios logo and the line beyond petroleum expressed the new identity of the company. It gave a strong message that BP was intent on becoming a new type of global energy enterprise. We meant to tell people that we were ready to do more than they would expect when it came to confronting difficult issues, such as the conflict between energy and environmental needs. ${ }^{127}$

The advertising agency that handled the BP account was bombarded by calls from other businesses asking them to remake their image in the same way that BP had, focusing on the future instead of the past. ${ }^{128}$

While Browne does address safety issues briefly-he mentions the leaking Alaska pipeline and the Texas City explosion as being low points for the company and his career - they are largely glossed over, constituting only twelve pages of an almost 300-page book. ${ }^{129} \mathrm{He}$

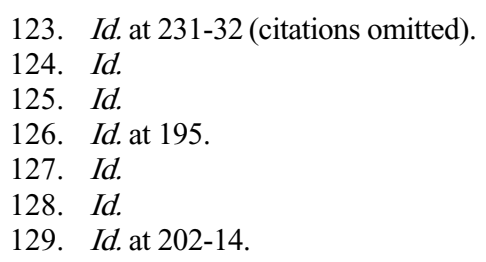


traces these safety problems to the BP-Amoco merger, noting that the Texas City refinery was an Amoco facility that had not been fully integrated into $\mathrm{BP}^{130}$ With more time and attention from $\mathrm{BP}$ management after the acquisition, he argues, these safety issues would not have occurred. ${ }^{131}$ Noting that BP had a "an aspiration of 'no accidents, no harm to people,"' Browne does acknowledge that an independent panel found that BP "had not done enough to make process safety a core value at Texas City, or the other four US refineries." "132

Putting those problems aside, Browne had, by his own account, tried to change the image of BP from the top down. In his words:

The image of the [oil] industry was that it was old-fashioned and dirty, and still secretive and manipulative. That was not the reality. We wanted our image to reflect what we believed BP now stood for. It was to be a competitively profitable force for good, which valued top-class safe operational performance, innovation, progress and environment leadership. ${ }^{133}$

This was Browne's vision of the company he had created, a vision that he shared with others, and a vision that others began to believe-all before one of the largest environmental tragedies in history occurred.

\section{Reception of the BP Advertising Campaign}

The BP advertising campaign was wildly successful. While the logic of an ecologically friendly oil company engaged in deepwater drilling is something of an oxymoron, ${ }^{134}$ BP's kinder, gentler image touched a nerve with American consumers. For whatever their own carbon footprints might be, for whatever gas-guzzling SUVs they or their neighbors might own, for however many trips consumers made in their cars, they at least aspired to be kinder to the environment. And

130. Id. at 205 ("Texas City was one of the refineries that had been part of Amoco for more than 70 years. It had a proud and long history. Its workforce felt that they were the heart and soul of the refinery. But I had a sense that they felt put upon; relations were not good between management and the rank and file. Changes of local leadership did little to improve the situation. I suspect that some of these issues got in the way of fully integrating Texas City with the rest of BP. Integration might have changed nothing but it also might have changed everything.").

131. Id.

132. Id.

133. Id. at 194

134. We note that environmental groups have been opposed to deepwater drilling, given the inherent environmental risks and the almost inescapable likelihood of serious environmental damage in the drilling process, as well as the risk of oil spills that will pollute the seas. 
these consumers wanted to patronize a "green" gasoline brand, and BP seemed to be that brand.

Not only were most American consumers taken in, but so were legal academic commentators, ${ }^{135}$ environmentalists, and corporate social responsibility watchdogs. ${ }^{136}$ For example, the vice president and chief social investment strategist at Calvert, one of the largest socially responsible mutual funds in the country, noted in a media interview that she loved the environment and so would go out of her way to fill up her car at a BP gasoline station. ${ }^{137}$ To be sure, there were some skeptics who either seemed confused at the idea of an eco-friendly oil company that engaged in offshore drilling or who recalled BP's pesky ongoing safety issues. ${ }^{138}$ Despite these naysayers, "Beyond Petroleum" was for many years an unqualified success. As just one measure of the company's success, during Lord Browne's years as CEO, BP's stock price doubled.

As for Browne's memoirs, they are somewhat tainted given their release only months before the Deepwater Horizon disaster. Overall, one might be tempted to dismiss the memoir as mere selfcongratulatory propaganda. Despite acknowledged flaws in BP's safety processes, Browne spends scant time discussing the leaking pipelines in Alaska or the explosion in Texas City. Instead, he chooses to burnish his accomplishments, most notably the CSR mantra. But

135. See, e.g., Elizabeth F. Brown, No Good Deed Goes Unpunished: Is There a Need for a Safe Harbor for Aspirational Corporate Codes of Conduct?, 26 YALE L. \& POL'Y REV. 367, 400 (2008) (noting BP had "higher standards" than other companies); Kevin Jackson, Global Corporate Governance: Soft LaW and Reputational Accountability, 35 BROOK. J. INT'L L. 41, 104 (2010) (listing BP along with American Apparel, Seventh Generation, Starbucks, Timberland, and Whole Foods as making "CSR . . a vital component of their brands and their core business policies"); Pitts, supra note 8, at 334 (noting BP's effort to "do good" by furnishing better stoves in India, which helped to reduce indoor air pollution and the rate of death in that country from lung diseases); Cynthia A. Williams, Civil Society Initiatives and "Soft Law" in the Oil and Gas Industry, 36 N.Y.U. J. INT'L L. \& PoL. 457, 489 (2004) ("Companies that are recognized as leaders in corporate social responsibility, such as BP ... have adopted Codes of Conduct that do not permit paying bribes."). We mention these articles not in any way to embarrass the authors; the fact is that BP did some good things but it also put out misleading information and, in fact, even misled those who were well-versed in the literature of CSR.

136. For example, Julie Fox Gorte, Vice President and Chief Social Investment Strategist at Calvert, noted that she would go out of her way to fill up at a BP gasoline station. Robert Leffel \& Victoria Sweeney, Doing the Right Thing: How Ethical Leadership Can Enhance a Company's Market Share, Profit, Brand Perception and Performance, ETHISPHERE, http://members.ethisphere.com/?doing_right_thing (last visited Feb. 27, 2011).

137. Id.

138. See, e.g., Michael R. Siebecker, Trust \& Transparency: Promoting Efficient Corporate Disclosure Through Fiduciary-Based Discourse, 87 WASH. U. L. REV. 115, 134 (2009) (noting that BP's poor safety record clashed with its professed good citizen image). 
was this ever reality? Or, was this merely rhetoric in order to advance the bottom line? Browne was certainly interested in growing the company; he notes that BP's growth into a truly global company was one of his accomplishments. Environmentalism and acknowledgment of the carbon emissions problem were perhaps means to an endclever ways of advancing the company's growth while only undertaking change at a surface level.

That is one reading of the memoir. But of course, every individual acts from a combination of various motivations, and perhaps Browne actually did believe in some of the progressive ideas that he espouses in his memoirs. While it is easy to think of a corporation as a single entity - as indeed it is under the law — as a practical matter, those who cut corners out in the field and held supervisory positions with regard to safety issues may have been very different individuals, in terms of politics, values, pay, socio-economic class, and so forth, from those who were advocating the socially-responsible green image.

Browne notes that the rebranding met with some resistance and skepticism within the company. Further, John Browne's memoir highlights the true extent of the disconnect between what BP said it stood for and the company it actually was. Reading the book, one would find it difficult to believe that BP, and not some other oil company, was responsible for the worst oil spill in US history. The memoir, if nothing else, now seems downright misguided and misleading, as do many of BP's advertisements. If the public felt betrayed, it was because BP led people to believe that this company was different from other oil companies in a way that they wantedneeded - to hear. But it was all a glittering public relations campaign, not the harsh reality of BP's short-term bottom line. With this background on the myth and reality of BP, we now turn to discuss the corporate governance problems that led to the disaster-how they arose, and how they might be prevented in the future.

\section{Corporate LaW's Role In THE BP OIL SPILL}

We now explore the source of the gap between myth and reality at BP and by extension, other mainstream corporations. How could Lord Browne pride himself on creating a green oil company amid the history of environmental and safety problems that presaged the Gulf disaster? Perhaps corporate law and culture created and even dictated this disconnect. The following sections analyze these corporate laws after a brief primer on CSR and the levels at which businesses may integrate it into their operations. 


\section{A. Levels of Corporate Social Responsibility}

As Lord Browne's memoir proudly states, CSR takes a wider view of a corporation's purpose beyond profit. ${ }^{139}$ Rather, firms wishing to be socially responsible should strive to be "useful to society," as well. ${ }^{140}$ As Lord Browne articulated it, this meant fulfilling society's current energy needs (for matters such as heat, light, and mobility), while using its vast resources to tackle such difficult issues as climate change, pollution, and the development of viable alternatives to fossil fuels. ${ }^{141}$ More generally, CSR means managing a business with equal regard for financial performance, environmental consequences, and social impact.

One way of putting CSR into practice is to view these three goals as related bottom lines to be managed. ${ }^{142}$ That is, in addition to "the traditional bottom line of financial performance (most often expressed in terms of profits, return on investment (ROI), or shareholder value)," a firm should also mind its "impact on the broader economy, the environment, and on the society in which [it] operate[s]."143 This triple focus often improves firms' financial bottom lines as much as it helps the environment and society. To take one example, efforts to reduce manufacturing waste often result in greater efficiency and the discovery of innovative techniques and materials, all of which in turn can benefit the firm, its workforce, and the environment in both the short and the long runs..$^{144}$

Firms may integrate these concepts in their operations to varying degrees. At one end of the spectrum, a firm may have no ambition to be socially responsible and in fact be out of compliance with

139. BROWNE, supra note 93, at 231-32.

140. Id.

141. Id.

142. John Elkington, CAnNibals with Forks: The Triple Bottom Line of 21st Century Business (1998)

143. See Andrew W. Savitz with Karl Weber, The Triple Bottom Line: How TODAY's Best-Run COMPANIES ARE ACHIEVING ECONOMIC, SOCIAL, AND ENVIRONMENTAL SUCCESS-AND HOW YOU CAN TOO, at xii (2006). Elkington notes that, by considering society and the environment, the triple bottom line internalizes costs that firms would otherwise externalize. ELKINGTON, supra note 142, at 92-94, 307 (discussing the "full cost accounting" method of "assessing the total cost of making, using, and disposing of products").

144. ElKington, supra note 142, at 314 (discussing DuPont's successful 99\% reduction in toxic emissions at a Texas plant- "achieved through the use of closed-loop recycling, off-site reclamation, selling former wastes as products, and substituting raw materials"-which saved "\$2.5 million of capital and more than $\$ 3$ million in annual operating costs"); SAVITZ, supra note 143 (containing numerous such anecdotes). 
applicable labor and environmental laws and regulations. ${ }^{145}$ At this first type of firm, the focus is on profits to the exclusion of all other considerations and the firm may even deliberately violate laws in order to maximize corporate profits. ${ }^{146}$

Slightly more socially responsible is a second type of firm that complies with applicable laws and perhaps engages in small amounts of generic corporate philanthropy, but does little beyond that. ${ }^{147}$ These firms see "no business case" for going beyond compliance or serving stakeholders' interests. ${ }^{148}$ To these firms, "the business of business is business" and by bare compliance (and paying taxes) they see themselves as fulfilling their societal obligations.

A third type of firm moves beyond bare compliance but only does so where it would be profitable. ${ }^{150}$ These firms may view CSR primarily as a public relations matter, for particularly in consumerfocused industries, social responsibility attracts customers and social irresponsibility repels them. ${ }^{151}$ These companies may also pursue a socially responsible agenda to save resources, reduce waste, achieve production efficiencies, and anticipate changing conditions,

145. Marcel van Marrewijk \& Marco Werre, Multiple Levels of Corporate Sustainability, 44 J. Bus. ETHICS 107, 112 (2003) (terming this level "pre corporate sustainability"); Kerr, supra note 9, at 857 (arranging corporate social responsibility levels along a spectrum). Interestingly, Van Marrewijk and Werre derive their levels of corporate social responsibility from Clare Graves's psychology research on value systems and levels of existence. Van Marrewijk \& Werre, supra, at 108.

146. On intentional noncompliance to maximize profits, see infra notes $185-188$ and accompanying text.

147. See SustainAbility Ltd., Gearing Up: From Corporate Responsibility to Good Governance AND Scalable Solutions 34-37 (2004) [hereinafter Gearing Up] (terming this category "compliance"); Van Marrewijk \& Werre, supra note 145, at 112 (terming this category "compliance-driven" corporate sustainability); Kerr, supra note 9, at 857 (terming this category "mere or reactive compliance").

148. GEARING UP, supra note 147 , at 35.

149. Id. (paraphrasing Milton Friedman).

150. Id. (labeling this type of firm a corporate social responsibility "volunteer"); Van Marrewijk \& Werre, supra note 145, at 112 (describing this level as "profit-driven" corporate sustainability).

151. Ray Fisman et al., Corporate Social Responsibility: Doing Well by Doing Good? (Sept. 2005) (unpublished manuscript) (on file at http://apps.olin.wustl.edu/jfi/pdf/ corporate.social.responsibility.pdf) (noting that CSR is more positively related to profitability in advertising-intensive, consumer-oriented industries); Janet E. Kerr, Sustainability Meets Profitability: The Convenient Truth of How the Business Judgment Rule Protects a Board's Decision To Engage in Social Entrepreneurship, 29 CARDOZO L. REV. 623, 664-65 (2007) (citing studies measuring "a strong positive relationship between CSR behaviors and consumers' reactions to a company's products and services"). This may be the case in business-to-business transactions, as well. See ELKINGTON, supra note 142, at 110, 119 (relating anecdotes). 
regulations, and consumer preferences. ${ }^{152}$ These firms may incorporate environmental, ethical, and social considerations at all levels of their operations and decision making, but only act upon them when it would benefit their financial bottom line. ${ }^{153}$

A fourth type of firm routinely balances economic, social, and environmental considerations and does so not in order to comply with applicable laws or to make a profit. ${ }^{154}$ Rather, these firms are motivated to "do good"- - for their various constituencies and for the planet—while still producing returns for their shareholders. ${ }^{155}$ These firms also tend to be more pro-active, partnering with government, "suppliers, customers, and others in their industry" to innovate sustainable solutions to environmental and other problems together. ${ }^{156}$

At the next level of CSR, firms integrate social responsibility principles into their strategy and business processes (starting with product or service development) such that the way of doing business is "built in, not bolted on."157 For example, companies at this stage may rethink their design and production processes to reduce waste, utilize improved, sustainable, and even reusable materials, and in some cases eliminate the use of harmful materials altogether. These firms aim to serve all their stakeholders, creating value for shareholders by matching "corporate objectives [with] wider societal challenges."158

At the sixth and highest level, CSR "is fully integrated and embedded in every aspect of the organization, aimed at contributing to the quality and continuation of life of every being and entity, now and

152. See Jayne W. Barnard, Corporate Boards and the New Environmentalism, 31 WM. \& MARY ENVT'L L. \& POL'Y REV. 291, 291 (2007) (noting that “sophisticated corporate managers" are "tak[ing] into account the possibility of increased governmental regulation; the increasing risk of a costly response to changing environmental conditions ...; and growing consumer preference for products sold by companies that are good corporate citizens").

153. Van Marrewijk \& Werre, supra note 145, at 110.

154. GEARING UP, supra note 147, at 35 (labeling this the "partner" level); Van Marrewijk \& Werre, supra note 145, at 112 (describing this level as "caring" corporate sustainability); Kerr, supra note 9, at 857-58 (labeling these firms "pro-active" in corporate social responsibility).

155. Van Marrewijk \& Werre, supra note 145, at 110.

156. Judd F. Sneirson, Green Is Good: Sustainability, Profitability, and a New Paradigm for Corporate Governance, 94 IowA L. REV. 987, 993 (2009) (internal quotation marks omitted); see also Van Marrewijk \& Werre, supra note 145, at 110.

157. See GEARING Up, supra note 147, at 36 (labeling this level "integrate"); Van Marrewijk \& Werre, supra note 145, at 112 (describing this level as "synergistic" corporate sustainability); Cynthia A. MCEwEn \& JOHN D. SCHMIDT, LEADERSHIP AND THE CORPORATE SustainABILITY CHALLENGE 17 (2007) ("What you have to do is build responsibility into every aspect of the way you do business, so it's built in, not bolted on." (quoting a pharmaceutical manufacturer's vice president of corporate responsibility)).

158. GEARING UP, supra note 147 , at 36. 
in the future."159 Here, companies also redesign or "reengineer" their business models, financial institutions, and markets to identify and root out any underlying causes inconsistent with social responsibility.

Aside from a few outliers, however, business rarely moves beyond the higher levels of CSR. ${ }^{160}$ This encompasses a great deal of socially responsible behavior and business practices, to be sure. Several studies report that socially responsible business practices tend to be profitable, ${ }^{161}$ and the popular business press is replete with anecdotal evidence in further support of this hypothesis. ${ }^{162}$ In addition, recent work by noted financial economist Michael Jensen suggests, along similar lines, that managing a firm in a socially responsible way

159. Id. (calling this level "reengineer"); Kerr, supra note 9, at 858 (calling this "creative capitalism"); Van Marrewijk \& Werre, supra note 145, at 112 (terming this level "holistic" corporate sustainability)

160. See, e.g., Murray Carpenter, A Coffee Conundrum, N.Y. TIMEs, Aug. 4, 2010, at B1 (profiling Green Mountain Coffee Roasters); Cornelia Dean, Executive on a Mission: Saving the Planet, N.Y. Times, May 22, 2007, at F1 (profiling Ray Anderson of Interface Carpets); Tom Foster, Patagonia's Founder on Why There's "No Such Thing as Sustainability," FAST COMPANY, July 1, 2009, http://www.fastcompany.com/magazine/ 137/no-such-thing-as-sustainability.html; Sarah Lyall, Anita Roddick, Body Shop Founder, Dies at 64, N.Y. TIMES, Sept. 12, 2007, at C11; Andrew Martin, Is a Food Revolution Now in Season?, N.Y. TIMES, Mar. 22, 2009, at BU1 (interviewing Stonyfield Farms CEO ("CE-Yo") Gary Hirshberg); Booth Moore, Toms Shoes' Model Is Sell a Pair, Give a Pair Away, L.A. TIMES, Apr. 19, 2009, http://www.latimes.com (enter "toms shoes model" in search box, with quotes); Danielle Sacks, Jeffrey Hollender: Seventh Generation, Triple Bottom Line Entrepreneur, FAST COMPANY, Feb. 2, 2010, http://fastcompany.com/article/Jeffrey-hollenderseventh-generation-triple-bottom-line-entrepreneur; Seth Goldman: Brewing Organic Tea with a Mission-Based Business Model, Knowledge@Wharton (Dec. 23, 2008), http://knowledge.wharton.upenn.edu/article.cfm?articleid=2124 (interviewing Honest Tea cofounder and CEO ("TeaEO") Seth Goldman).

161. Joshua D. Margolis et al., Does It Pay To Be Good? A Meta-Analysis and Redirection of Research on the Relationship Between Corporate Social and Financial Performance 21 (July 26, 2007) (unpublished manuscript) (on file at http://stakeholder.bu.edu /2007/docs/materials.html). The percentages do not total one hundred because thirteen percent of the studies did not use statistically significant sample sizes. An earlier meta-study reached similar results. Marc Orlitzky et al., Corporate Social and Financial Performance: $A$ Meta-Analysis, 24 ORG. STUD. 403, 427 (2003) (“[P]ortraying managers' choices with respect to [sustainability and profitability] as an either/or trade-off is not justified in light of 30 years of empirical data."). A more recent, individual study concludes that voluntary overcompliance beyond applicable environmental regulations does sacrifice shareholder profits, albeit only very slightly. Karen Fisher-Vanden \& Karin S. Thorburn, Voluntary Corporate Environmental Initiatives and Shareholder Wealth 2 (CEPR Discussion Paper No. 2008), available at $\mathrm{http} / / / \mathrm{ssrn} . \mathrm{com} / \mathrm{abstract}$ id $=1141020$ (reporting that overcompliance depressed firms' stock prices by about one percent).

162. See, e.g., Allison Linn, Wal-Mart Aims To Cut Energy Use- and Costs, MSNBC (Apr. 19, 2007), http://www.msnbc.msn.com/id/18075223. 
best enhances the long-term value of the firm for shareholders and stakeholders alike. ${ }^{163}$

What is more, all of these profitable, socially responsible business practices can together have an enormous impact. Whether Wal-Mart, to take one example, is motivated by profit or by a genuine care for the environment, the energy it saves by implementing fuelconservation measures in its fleet of delivery trucks is staggering. ${ }^{164}$ Likewise, its efforts to reduce its suppliers' packaging waste stand to save both energy costs and other resource consumption at Wal-Mart and at other retailers, as well. ${ }^{165}$ "The company is so big, and the network of companies that supply its products so vast, that experts see the potential for Wal-Mart to have a tangible impact on problems such as greenhouse gas emissions.",166

BP stands as a depressing counterpoint to these success stories. On the one hand, the company expended significant effort and resources successfully branding itself as a kinder, gentler, and greener oil company, committed to taking the world "Beyond Petroleum" to cleaner, renewable alternative energy sources. And the company appeared outwardly to be committed toward this goal, breaking from other oil companies on the issue of climate change, and contributing to environmental and other charitable causes. ${ }^{167}$ At the same time, however, the company flouted workplace regulations designed to protect employee safety, ignored environmental laws for oil and profit, ${ }^{168}$ and took enormous risks in deep-sea oil exploration that eventually led to the oil-rig explosion and ensuing spill-actions that proved anything but profitable. ${ }^{169}$

In other words, while much of BP's rhetoric exemplified CSR, the reality was that BP was focused primarily on profitability. That is, BP, like many companies, acted in an environmentally and socially responsible manner when and only when CSR helped its "green" image or would otherwise prove profitable. Otherwise, when profits

163. See generally Michael C. Jensen, Value Maximization, Stakeholder Theory, and the Corporate Objective Function, 12 Bus. ETHICs Q. 235 (2002) (positing that a firm best maximizes its long-term value by tending to all of its stakeholder groups).

164. See Linn, supra note 162.

165. See id.

166. See id.

167. Supra notes 3, 101, 116-117 and accompanying text.

168. See supra Part II.B.

169. See supra notes $19,70,79$ and accompanying text. 
and public relations were not at issue, BP eschewed its stated CSR tenets for the traditional way of doing business. ${ }^{170}$

\section{B. Shareholder Primacy and Profit}

What accounts for the stark disconnect between BP's carefully cultivated green image and its business-as-usual priorities? And why is CSR unable to move beyond a profit-driven level, or to instill more deeply committed practices and attitudes in mainstream businesses? The answers to both of these questions lie in the prevailing view in the legal academy and the business world that corporations are to be managed with a view toward maximizing shareholder profits.

This attitude - dubbed "shareholder primacy" in the academic literature - prioritizes shareholder interests above all other corporate constituencies, such as a corporation's employees, its trade creditors, and the communities in which it does business. ${ }^{171}$ According to this view, corporate managers must make as much profit as they possibly can, and they may not sacrifice profits for the sake of employees or other nonshareholder groups. For example, the firm should spend money on employee safety only to the extent necessary to comply with applicable laws and regulations or to the extent such expenditures are otherwise financially justifiable (in that they improve employee morale, attendance, or productivity, or that they result in lower insurance premiums or other corporate outlays). ${ }^{172}$

The most famous articulation of the shareholder primacy view appears in Dodge v. Ford Motor Co. ${ }^{173}$ There, John and Horace Dodge - then minority shareholders in the Ford Motor Companychallenged the decision of company founder and majority shareholder Henry Ford to suspend the company's practice of paying special

170. What is more, by holding itself out as a level five or six company, when in reality it was only at level one, BP "free rode" on the CSR efforts of other firms and the public's goodwill toward companies involved in socially responsible practices. The gap that BP so effectively exploited - taking advantage of the public relations upside of CSR without actually expending the time or money to integrate or engage in it - is especially dangerous, because it erodes the public's positive sentiment toward companies that genuinely engage in meaningful CSR.

171. See D. Gordon Smith, The Shareholder Primacy Norm, 23 J. CoRP. L. 277, 29091 (1998).

172. Even a violation of a workplace safety law might contribute to shareholder profit maximization in that the amount of money saved or made may well outweigh any potential penalties (discounted according to the likelihood of being caught, prosecuted, and found liable). See infra notes 185-188 and accompanying text.

173. 170 N.W. 668 (Mich. 1919). 
dividends. ${ }^{174}$ Ford instead sought to direct the firm's resources toward expanding its business, lowering the price of its cars, and paying the company's workers better wages. ${ }^{175}$ While these decisions seem reasonable enough, Ford inadvisably testified at trial that he believed the company made too much money and that he would prefer it to be less profitable. ${ }^{176}$

Seizing on this testimony, the Dodge brothers argued, and the Supreme Court of Michigan agreed, that Ford's actions perverted the corporation's shareholder-profit purpose. The court explained:

A business corporation is organized and carried on primarily for the profit of the stockholders. The powers of the directors are to be employed for that end. The discretion of directors is to be exercised in the choice of means to attain that end, and does not extend to a change in the end itself, to the reduction of profits, or to the nondistribution of profits among stockholders in order to devote them to other purposes. ${ }^{177}$

While the court ultimately deferred to Ford's business judgment, it ordered the company to declare a special shareholder dividend. ${ }^{177}$

Although subsequent courts have not relied much on Dodge's authority, the case and its statement of shareholder primacy have taken on lives of their own in law school casebooks, in the academic literature, and in the minds and hearts of American businesspeople. ${ }^{179}$ In fact, in large part due to Dodge, American corporate culture has embraced shareholder primacy and profit maximization as norms. ${ }^{180}$

174. Id. at 671. The company had five other shareholders in addition to Ford and the Dodge brothers, and had regularly paid out generous special dividends. Id. at 670; STEPHEN M. BAINBRIDGE, CORPORATION LAW AND ECONOMICS $\S 9.23$, at 411 (2002).

175. Dodge, 170 N.W. at 671.

176. Id. at 683-84; see also Jonathan R. Macey, A Close Read of an Excellent Commentary on Dodge v. Ford, 3 VA. L. \& Bus. REv. 177, 181-84 (2008) (suggesting that had Ford been less forthright on the stand, he would have easily won the case).

177. Dodge, 170 N.W. at 684 ("[I]t is not within the lawful powers of a board of directors to shape and conduct the affairs of a corporation for the merely incidental benefit of shareholders and for the primary purpose of benefiting others.").

178. Id. at 685. The court did not interfere with Ford's decision to expand the company's operations, however, in a straightforward application of the business judgment rule. Id. at 684. Interestingly, the Dodge brothers used this money to finance their eponymous competitor, Dodge Brothers Company. See BAINBRIDGE, supra note 174, § 9.2, at 412 n. 4 (suggesting Ford's decision to cease special dividends "was a shrewd and ruthless attempt to stifle competition" and speculating that Ford did not testify as to this purpose because he "feared antitrust litigation" and "didn't want to look like a robber baron").

179. See Sneirson, supra note 156, at 1003-04.

180. Norms are "informal social regularities that individuals feel obligated to follow because of an internalized sense of duty, because of a fear of external non-legal sanctions, or both.” Richard H. McAdams, The Origin, Development, and Regulation of Norms, $96 \mathrm{MICH}$. L. Rev. 338, 340 (1997); LAWRENCE LESSig, CODE AND Other LAWS OF CyBERSPACE 235 
Thus, whether or not corporate law requires managers to maximize shareholder wealth, social norms induce many of them to do so, because that is what they learned in business school, because that is how they view their jobs, because they perceive that is what is expected of them, and because they believe - rightly or wrongly - that the law requires them to do so. ${ }^{181}$ Indeed, some conclude that these norms have "been fully internalized by American managers," 182 such that modern business practices could be said to follow Milton Friedman's famous credo that "the social responsibility of business is to increase its profits." 183

Executive compensation, particularly when it is tied to the company's stock price, may also exert pressure on corporate decision makers to maximize shareholder returns, especially in the short term. Judge Richard Posner recently argued that typical executive compensation packages also encourage excessive risk-taking:

[T] he stock-option method of compensating CEOs has been found to induce them to take excessive risks because of the asymmetry of gain and loss: there is no ceiling on the potential gain, but the loss is truncated at the value of the options.... Another questionable compensation practice is giving the CEO an employment contract entitling him to generous severance pay, so that if he is fired he is

(1999) (defining norms as "those normative constraints imposed not through the organized or centralized actions of a state, but through the many slight and sometimes forceful sanctions that members of a community impose on each other"); Cass R. Sunstein, Social Norms and Social Roles, 96 Colum. L. REv. 903, 914 (1996) (defining norms as "social attitudes of approval and disapproval, specifying what ought to be done and what ought not to be done"). See generally Symposium, Norms \& Corporate Law, 149 U. PA. L. REV 1607 (2001).

181. See Milton Friedman, The Social Responsibility of Business Is To Increase Its Profits, N.Y. TIMES, Sept. 13, 1970, at 33; see also Jill E. Fisch, Measuring Efficiency in Corporate Law: The Role of Shareholder Primacy, 31 J. CoRP. L. 637, 654-55 (2006) (noting a study finding "that the norm of shareholder wealth maximization was implicit in most business school courses"); Mark J. Roe, The Shareholder Wealth Maximization Norm and Industrial Organization, 149 U. PA. L. REV. 2063, 2073 (2001) ("Norms in American business circles, starting with business school education, emphasize the value, appropriateness, and indeed the justice of maximizing shareholder wealth."); id. at 2065 ("Shareholder wealth maximization is usually accepted as the appropriate goal in American business circles.").

182. Stephen M. Bainbridge, Participatory Management Within a Theory of the Firm, 21 J. CoRp. L. 657, 717 (1996); Lawrence E. Mitchell, A Critical Look at Corporate Governance, 45 VAND. L. REV. 1263, 1288 (1992) ("Directors seem to believe that their legal duty is to the stockholders.").

183. Fisch, supra note 181, at 655; see Smith, supra note 171, at 290-91 ("[M] anagers often make decisions that do not maximize value for shareholders."); Milton Friedman, The Social Responsibility of Business Is To Increase Its Profits, N.Y. Times, Sept. 13, 1970, (Magazine), at 33 (also quipping that "the business of business is business"). Gordon Smith and Jill Fisch caution that the legal literature overstates this norm. 
cushioned against loss. This reinforces his incentive to take excessive risks, and at the same time signals his lack of self-confidence. ${ }^{184}$

This profit-maximization approach even colors executives' views of the firm's legal obligations. While corporations and their fiduciaries must obey the law, ${ }^{185}$ profit-maximizing firms often consider compliance optional and related fines and penalties mere costs of doing business. ${ }^{186}$ That is, if the profit to be made by breaking a law outweighs the associated penalty-discounted by the likelihood the firm will be caught and made to pay the penalty at whatever point in the future - the firm should break the law to maximize shareholder profit. In other words, "[t]he obligation to obey the law is subservient to the obligation to make money." 187 This view of "law as price" may help explain much of BP's poor compliance record in its U.S. operations. ${ }^{188}$

American corporate law, both in Delaware and in other states, encourages this view. Although no corporate law explicitly requires corporate managers to maximize shareholder wealth, the cases suggest as much. ${ }^{189}$ For example, under Delaware law, corporate decision makers may have regard for nonshareholder constituencies but any decisions that benefit these stakeholders must benefit the firm's shareholders, as well. ${ }^{190}$ Thus, in choosing between two competing

184. Richard A. Posner, Are American CEOs Overpaid, and, If So, What If Anything Should Be Done About It? 58 DuKE L.J. 1013, 1026-27 (2009).

185. See Miller v. Am. Tel. \& Tel. Co., 507 F.2d 759, $762-63$ (3d Cir. 1974).

186. Robert Cooter, Prices and Sanctions, 84 Colum. L. REV. 1523, 1524-25 (1984); Frank H. Easterbrook \& Daniel R. Fischel, Antitrust Suits by Targets of Tender Offers, 80 Mich. L. ReV. 1155, 1168 n.37 (1982); David Engel, An Approach to Corporate Social Responsibility, 32 STAN. L. REV. 1 (1979). These authors make exceptions for certain laws, "law[s] that prohibit[] mala in se actions, such as those constituting violence (Easterbrook and Fischel); actions that are deemed morally reprehensible by a clear social consensus (Pepper); and actions that involve criminal or moral norms (Ginsburg)." Cynthia A. Williams, Corporate Compliance with the Law in the Era of Efficiency, 76 N.C. L. REv. 1265, 1324 (1998) (referring to Stephen L. Pepper, Counseling at the Limits of the Law: An Exercise in the Jurisprudence and Ethics of Lawyering, 104 YALE L.J. 1545 (1995); Smith v. Nat'l Transp. Safety Bd., 981 F.2d 1326 (D.C. Cir. 1993) (D.H. Ginsburg, J.)).

187. Kent Greenfield, The Failure of Corporate LaW: Fundamental FlaWs AND Progressive Possibilities 73-74 (2006). Greenfield argues that courts should treat decisions not to comply with applicable laws as ultra vires and hold decisionmakers personally liable to the corporation for any fees and penalties. Id.

188. See supra Part II.B.

189. Sneirson, supra note 156, at 995-1007 (arguing that American corporate law contains no requirement of shareholder profit maximization).

190. See Revlon, Inc. v. MacAndrews \& Forbes Holdings, 506 A.2d 173, 182 (Del. 1985) ("A board may have regard for various constituencies in discharging its responsibilities, provided there are rationally related benefits accruing to the stockholders."); see also eBay Domestic Holdings v. Newmark, No. 3705-CC, 2010 WL 3516473, at *22 (Del. Ch. Sept. 9, 
merger partners, a board may only opt for the less generous proposal if it represents a better strategic combination in the long run, preserves valuable company culture, or similarly enhances firm value in the long term. ${ }^{191}$ Similarly, in making normal operational decisions, corporate fiduciaries may only benefit nonshareholder constituencies or the environment if some benefit will ultimately redound to the shareholders, as well.

American corporate law also projects this shareholder-centric philosophy in describing the very nature of corporate fiduciaries' legal obligations. Although corporate fiduciary duties are generally understood to run to the enterprise, ${ }^{192}$ many judicial opinions state otherwise: "[C]orporate directors have a fiduciary duty to act in the best interests of the corporation's stockholders" ${ }^{\text {193 }}$ or alternatively that corporate fiduciaries must act in the best interests of the corporation and its shareholders. ${ }^{194}$ While, at least in the long run, there may not

2010) ("Promoting, protecting, or pursuing non-stockholder considerations must lead at some point to value for stockholders."). This rule and caveat apply to normal governance issues under Delaware corporate law; where the company is undergoing a "change in control" or sale and inevitable breakup, shareholder-centric duties kick in and preclude the board from sacrificing shareholder interests to serve other stakeholders. Revlon, 506 A.2d at 182.

Several American jurisdictions (but not Delaware) similarly restrict corporate charitable giving, requiring that donations benefit the firm in some way, even if the corporate benefit is indirect and somewhat tenuous. See Jesse H. ChOPER et Al., CASES \& Materials on CORPORATIONS 39 (6th ed. 2004) (noting that seven states allow donations regardless of corporate benefit, nineteen states require a corporate benefit (however tenuous), and twentyfour states (including Delaware) do not specify any such requirement). We note, but do not pursue, the point because there does not seem to be a crisis of corporate giving at present.

191. See, e.g., In re Time Inc. Shareholder Litig., 571 A.2d 1140 (Del. 1989) (validating Time's efforts to prefer Warner over Paramount as merger partners, which preference was ostensibly motivated to protect the "Time culture" of journalistic integrity). Again, this assumes Revlon duties have not been triggered. See GREENFIELD, supra note 187.

192. E. Norman Veasey \& Christine T. Di Guglielmo, How Many Masters Can a Director Serve? A Look at the Tensions Facing Constituency Directors, 63 Bus. LaW. 761, 764 (2008) (citing N. Am. Catholic Educ. Programming Found. v. Gheewalla, 930 A.2d 92, 101 (Del. 2007) ("It is well settled that directors owe fiduciary duties to the corporation."), among other cases).

193. Unocal Corp. v. Mesa Petroleum Co., 493 A.2d 946, 946 (Del. 1985) ("[O]ur analysis begins with the basic principle that corporate directors have a fiduciary duty to act in the best interests of the corporation's stockholders.").

194. Veasey \& Di Guglielmo, supra note 192, at 764 (citing a different passage in Gheewalla, 930 A.2d at 99 ("It is well established that the directors owe their fiduciary obligations to the corporation and its shareholders."), among other cases). For a cogent explanation of this inconsistency, see Lawrence E. Mitchell, A Theoretical and Practical Framework for Enforcing Corporate Constituency Statutes, 70 TEX. L. REv. 579, 590-96 (1992) (positing that courts speak in terms of the corporation's best interests when resolving a "vertical conflict of interest" between the firm and its managers, and the shareholders' best interests when resolving a "horizontal conflict of interest" between shareholders and other stakeholder groups). 
even be a discernable difference between these three statements, the recurring message is that shareholders and their profits trump all other considerations. $^{195}$

British company law takes an even stronger tack. ${ }^{196}$ Although the two nations' corporate laws are very similar, shareholders in British companies enjoy greater power than do their American counterparts. ${ }^{197}$ British directors as a result decidedly cater to shareholder interests. ${ }^{198}$ British statutes reinforce this hierarchy: while directors must consider nonshareholder interests in making company decisions, in the end they "must ... promote the success of the company for the benefit of its members [that is, its shareholders] as a whole.",199

As a result of these directives, BP and many American companies engage in CSR, if at all, only at the lower CSR levels described above.

195. Stephen M. Bainbridge, In Defense of the Shareholder Wealth Maximization Norm: A Reply to Professor Green, 50 WASH. \& LEE L. REV. 1423, 1439 (1993) ("In most situations, shareholder and nonshareholder constituency interests coincide."); Smith, supra note 171, at 285 ("“[T]he best interests of the corporation' are generally understood to coincide with the best long-term interests of the shareholders."); Veasey \& Di Guglielmo, supra note 192, at 764-65 \& n.9 (acknowledging that "operating a business in an environmentally sustainable way" may make "good business sense and therefore increase[] long-term financial value").

196. BP is, of course, a creature of British "company law," and thus British law governs its corporate governance and internal affairs. See BAINBRIDGE, supra note 174, $\S 1.3(\mathrm{~A})$, at 14 (discussing the internal affairs doctrine).

197. Christopher M. Bruner, Power and Purpose in the "Anglo-American" Corporation, 50 VA. J. INT'L L. 579, 580-82 (2010) ("Shareholders in the United Kingdom are ... far more powerful, and far more central to the aims of the corporation than are shareholders in the United States."). British shareholders can unilaterally amend the company's charter, pass special resolutions directing the board to act or refrain from acting in a certain way, remove directors, and play a commanding role in takeover attempts. Id.

198. Id. at 603.

199. The particular provision reads:

A director of a company must act in a way he considers, in good faith, would be most likely to promote the success of the company for the benefit of its members as a whole, and in doing so have regard (amongst other matters) to-

(a) the likely consequences of any decision in the long term,

(b) the interests of the company's employees,

(c) the need to foster the company's business relationships with suppliers, customers and others,

(d) the impact of the company's operations on the community and the environment,

(e) the desirability of the company maintaining a reputation for high standards of business conduct, and

(f) the need to act fairly as between members of the company.

Companies Act, 2006, c. 46, § 172(1) (U.K.); see also Bruner, supra note 197, at 607-08 ("Ultimately, however, as a formal matter, [stakeholder] considerations are relevant only to the extent that they relate to the actual duty imposed on directors to make a good faith effort to advance the shareholders' interests."). 
Only where profits may be made, either in terms of energy savings, waste reduction, or as a result of a benevolent corporate image, do socially responsible behaviors seem permissible. And if no profit potential presents itself and public relations do not appear to be at stake, American and British corporate law seems to require a shareholder focus, eschewing other considerations, maximizing profits, and perhaps violating environmental and other laws in dogged pursuit of them.

\section{Moving Beyond Profit}

One of us has argued elsewhere that American corporate law imposes no legal duty to manage firms in this way. ${ }^{200}$ That is, no corporate statute, legal rule, or controlling precedent requires shareholder profit maximization. ${ }^{201}$ To be sure, the Dodge case speaks in dicta of shareholder profit as the central purpose of the corporation, and three subsequent decisions contain similar expressions, also in dicta. ${ }^{202}$ But none of these cases stands for the legal proposition that a corporation must maximize shareholder profit, and in fact later decisions cite these cases only for other points of law. ${ }^{203}$

To the extent corporate law requires any shareholder focus, it stems from the Delaware legal principle, requiring decisions benefiting nonshareholder interests to benefit shareholders, and the British statute, requiring something similar of British company directors. ${ }^{204}$ Perhaps then the American Law Institute's Principles of Corporate Governance accurately summarizes corporate law on this point. ${ }^{205}$

200. See Sneirson, supra note 156 .

201. See id. at 995-1007.

202. See supra text accompanying note 177; Granada Invs., Inc. v. DWG Corp., 823 F. Supp. 448, 459 (N.D. Ohio 1993) ("[T] he sole duty of a corporation's officers is to maximize shareholder wealth.”); Katz v. Oak Indus., Inc., 508 A.2d 873, 879 (Del. Ch. 1986) ("It is the obligation of directors to attempt, within the law, to maximize the long-run interests of the corporation's stockholders."); Long v. Norwood Hills Corp., 380 S.W.2d 451, 454 (Mo. Ct. App. 1964) (" $[\mathrm{T}]$ he ultimate object of every ordinary trading corporation is the pecuniary gain of its stockholders.").

The recent decision in eBay Domestic Holdings, Inc. v. Newmark, 3705-CC, $2010 \mathrm{WL}$ 3516473 (Del. Ch. Sept. 9, 2010), suggests something similar, also in dicta. There, in invalidating the controlling shareholders' dead-hand poison pill, the Chancery Court wrote, "Having chosen a for-profit corporate form, the craigslist directors are bound ... to promote the value of the corporation for the benefit of its stockholders. The 'Inc.' after the company name has to mean at least that." Id. at *23. This statement is closer to the Delaware requirement that corporate decisions ultimately benefit the firm's shareholders, see discussion supra note 190, than a requirement to maximize, as oppose to promote, shareholder welfare.

203. Sneirson, supra note 156, at 1003-04.

204. Supra notes 190, 199 and accompanying text.

205. AM. L. INST., PRINCIPLES OF CORPORATE GOVERNANCE (1994). 
According to the ALI, "a corporation ... should have as its objective the conduct of business activities with a view to enhancing corporate profit and shareholder gain." 206 This "enhancing" (as opposed to maximizing $)^{207}$ is to be over the long term, ${ }^{208}$ and firms may also pursue limited objectives beyond profit and shareholder gain:

Even if corporate profit and shareholder gain are not thereby enhanced, the corporation, in the conduct of its business ... [m] ay take into account ethical considerations that are reasonably regarded as appropriate to the responsible conduct of business; and ... [m]ay devote a reasonable amount of resources to public welfare, humanitarian, educational, and philanthropic purposes. ${ }^{209}$

What is more, even if one accepts the view that corporate law requires fiduciaries to focus on shareholder wealth, the business judgment rule affords corporate decision makers so much latitude as to render any such duty unenforceable and meaningless. ${ }^{210}$ Under the business judgment rule, courts defer to fiduciaries' business judgments as long as there is no conflict of interest present and the decision is reached conscientiously, on the basis of reasonably full information, and with a good-faith belief that the decision is in the best interests of the firm. ${ }^{211}$ As long as these predicates are met, company decisions,

206. Id. § 2.01(a).

207. William W. Bratton, Confronting the Ethical Case Against the Ethical Case for Constituency Rights, 50 WASH. \& LEE L. REV. 1449, 1456 (1993) (noting that the ALI eschews the term "maximization" for the more equivocal term "enhancement").

208. AM. L. INST., supra note $205, \S 2.01$ (a) cmt. f ("[E]nhancing corporate profit and shareholder gain ... does not mean that the objective of the corporation must be to realize corporate profit and shareholder gain in the short run."); see also id. illus. $1 \& 2$.

209. Id. § 2.01(b).

210. See Macey, supra note 176, at 180-81 (arguing that corporate law requires shareholder wealth maximization but conceding that, like the speed limit on the Merritt Parkway, it is not enforced because enforcement would prove to be difficult or impossible); Roe, supra note 181, at 2072 (noting that "corporate law's instructions to managers" to enhance shareholder gain do not "determine what they do"); Smith, supra note 171, at 286 ("[T]he business judgment rule makes the shareholder primacy norm virtually unenforceable against public corporations' managers."); see also Fisch, supra note 181, at 651 ("Although Dodge v. Ford is frequently cited, no modern court has struck down an operational decision on the ground that it favors stakeholder interests over shareholder interests."); Thomas W. Joo, Race, Corporate Law, and Shareholder Value, 54 J. Legal EduC. 351, 361 (2004) ("[D]irectors' supposed duty to 'maximize' shareholder wealth is a toothless one. No courts actually require management to maximize shareholder wealth .... Indeed, such a showing would be all but impossible.").

211. See Joy v. North, 692 F.2d 880, 885-86 (2d Cir. 1982) (presenting rationales for the business judgment rule); William T. Allen et al., Function over Form: A Reassessment of Standards of Review in Delaware Corporation Law, 56 Bus. LAw. 1287, 1297 (2001) (describing the business judgment rule as "an expression of a policy of non-review of a board of directors' decision"); see also BAINBRIDGE, supra note 174, §6.2, at 242 (viewing the 
including decisions that depart from a profit-maximizing objective, will always stand. ${ }^{212}$

Although British company law has no business judgment rule per se, standing rules and lenient standards of review achieve much the same result. Fiduciary duties in British firms are owed to the company alone, and British law restricts the ability of shareholders to sue derivatively on the company's behalf. ${ }^{213}$ In addition, directors' duties to pursue shareholders' interests are judged according to a subjective standard - whether directors have made a good faith effort to advance shareholder interests. ${ }^{214}$ These two features of British company law, like the American business judgment rule, "render it quite difficult for U.K. shareholders to bring suit" to challenge a decision as insufficiently profitable. ${ }^{215}$

Lastly, most American corporation codes contain provisions reaffirming this stance. These "other constituency" statutes further protect business decisions made in the interests of the entire firm, typically stating that directors and officers may consider all of the firm's constituencies — not just its shareholders - when determining what constitutes the company's best interests. ${ }^{216}$ About two-thirds of these provisions are generally applicable, providing an extra measure of comfort where corporate managers make decisions that serve the

business judgment rule as an abstention doctrine). For a discussion of whether the business judgment rule should apply to corporate officers or just to directors, see Lyman P.Q. Johnson, Corporate Officers and the Business Judgment Rule, 60 BuS. LAW. 439 (2005). For an analysis of the "reasonably full information" predicate, see Sneirson, supra note 8, at 465-68 (arguing that the duty of care's reasonably full information component requires fiduciaries to assess and consider effects on the firm's nonshareholder constituencies).

212. See, e.g., Joy, 692 F.2d at 880; Gagliardi v. TriFoods Int'l, Inc., 683 A.2d 1049, 1052 (Del. Ch. 1996); Shlensky v. Wrigley, 237 N.E.2d 776 (Ill. App. Ct. 1968) (upholding the decision not to install lights at Wrigley Field); Kamin v. Am. Express Co., 383 N.Y.S.2d 807 (Sup. Ct. 1976) (upholding a dividend that squandered a sizable corporate tax deduction).

213. Bruner, supra note 197, at 609.

214. Id.

215. Id.

216. The Illinois provision is typical of the American statutes. It provides:

In discharging the duties of their respective positions, the board of directors, committees of the board, individual directors and individual officers may, in considering the best long term and short term interests of the corporation, consider the effects of any action (including without limitation, action which may involve or relate to a change or potential change in control of the corporation) upon employees, suppliers and customers of the corporation or its subsidiaries, communities in which offices or other establishments of the corporation or its subsidiaries are located, and all other pertinent factors.

805 ILl. COMP. STAT. 5/8.85 (1983). Most of the states that enacted these provisions did so during the surge of corporate-takeover activity in the 1980s, often to help local corporations fend off out-of-state suitors. See Sneirson, supra note 156, at 997-98. 
firm through its nonshareholder constituencies; the remaining third are limited to the takeover context and therefore only offer this statutory protection to a narrower class of decisions. ${ }^{217}$

In sum, while the law directs or at least encourages corporate fiduciaries to maximize shareholder wealth, it simultaneously refuses to enforce any such requirement. What accounts for this major contradiction? ${ }^{218}$ Perhaps the shareholder wealth maximization object is simply official guidance meant to reinforce the profit-centered norm, in recognition of the business judgment rule's inherent incompatibility with decisionmaking directives. ${ }^{219}$ Whatever the reason, corporate law perpetuates this ambivalence, lending support to both the view that corporations exist to serve their shareholders through profit maximization and the view that they may safely serve other constituencies as well, acting not just for shareholders but rather in the best interests of the entire enterprise. ${ }^{220}$

217. See Sneirson, supra note 156, at $998 \mathrm{nn} .52-53$ (citing these statutes).

218. See William T. Allen et al., The Great Takeover Debate: A Meditation on Bridging the Conceptual Divide, 69 U. CHI. L. REv. 1067 (2002); Christopher M. Bruner, The Enduring Ambivalence of Corporate Law, 59 ALA. L. REV. 1385 (2008); Lyman Johnson, The Delaware Judiciary and the Meaning of Corporate Life and Corporate Law, 68 TEX. L. REV. 865, 902 (1990).

219. Brett McDonnell, Comment to Judd Sneirson, Shareholders Versus Stakeholders (May 5, 2010, 8:00 AM), http://www.professorbainbridge.com/professorbainbridgecom /2010/05/shareholders-versus-stakeholders.html ("[Perhaps] courts put forth a norm that boards should maximize return to shareholders but outside a few special circumstances they do not enforce that norm in a way that gives rise to liability for violating it.").

220. An alternative explanation for the BP oil spill places blame on BP management's inability to direct its subordinates to carry out its objectives and monitor their subsequent actions. Whether or not they reflect reality, Lord Browne's legacy-creating memoir and Tony Hayward's ignorance-pleading congressional testimony both support this hypothesis. Corporate law has traditionally viewed such director inattention as a question of the duty of care. In In re Caremark, the Delaware Chancery Court set the modern standard for failure to monitor claims, noting the importance of "relevant and timely information" for the board of directors to satisfy its statutory role as the supervisor and monitor of the corporation's business and affairs, see DEL. CODE ANN. tit. 8, § 141(a) (2010), and requiring boards to "assur[e] themselves that information and reporting systems exist in the organization [and] are reasonably designed to provide ... accurate information sufficient to allow management ... to reach informed judgments concerning both the corporation's compliance [with its legal obligations] and its business performance.” 698 A.2d 959, 970 (Del. Ch. 1996). For such a breach to be actionable, director inattention must rise to a "sustained or systematic failure of the board to exercise oversight." Id.; see also Stone v. Ritter, 911 A.2d 362, 369-70 (Del. 2006) ("[D]irector oversight liability [attaches when] (a) the directors utterly fail[] to implement any reporting or information system or controls; or (b) having implemented such a system or controls, [the directors] consciously fail[] to monitor or oversee its operations thus disabling themselves from being informed of risks or problems requiring their attention."). British boards have corresponding monitoring obligations, see Brian R. Cheffins \& Bernard S. Black, Outside Director Liability Across Countries, 84 TEX. L. REv. 1385, 1401 (2006), 


\section{SOlutions: TOWARd A SUBSTANTIVE TheORY OF CORPORATE SOCIAL RESPONSIBILITY}

The unprecedented magnitude of the BP oil spill, the live footage of it incessantly spewing into the Gulf of Mexico, and the heartbreaking imagery of oil-soaked waterfowl have perhaps provided the needed motivation for the nation to rethink its energy policies and institute greater environmental protections. To the extent the preceding parts are correct - to the extent that corporate law, no less than our energy priorities and environmental regulations, gave rise to the BP oil spill disaster - corporate law too is due for needed reform. This Part proposes such reforms in an effort to transform the crisis that is the BP oil spill into an opportunity for lasting change. ${ }^{221}$

\section{A. A Cause of Action for "Greenwashing" and "Faux CSR"}

Beyond the environmental damage, beyond the lives lost, beyond the ruins of the Gulf economy, there was another aspect of the oil spill that was especially galling to the public. Many felt a sense of betrayal, because, as we have noted, there was such an extreme disconnect between the spill and BP's advertising, which had portrayed the company as being different (read: better) than traditional oil companies. Consumers and the public therefore trusted BP and many went out of their way to purchase gasoline from BP when possible. ${ }^{222}$ Socially conscious investors purchased BP stock, believing the claims that BP was engaged in better environmental practices than its competitors. Those investor and consumer expectations were built through BP's own advertising that challenged the traditional view of an oil company; acknowledgement of difficult environmental problems, most notably climate change; and the necessity of exploring forms of alternative fuels. ${ }^{223}$

To understand the sense of consumer betrayal, it may be helpful to offer a few comparisons. While people might not be shocked or upset to find out that Kathie Lee Gifford's clothing line was (once

and some of the many derivative actions filed in respect of the oil spill advance such allegations.

221. Despite the common assertion, the Chinese character for "crisis" does not also mean "opportunity." See PINYIN.INFO, http://www.pinyin.info/chinese/crisis.html (last visited Feb. 27, 2011)

222. See supra note 106 and accompanying text.

223. Others have noted that CSR involves a level of trust that is undermined when companies do not carry out CSR programs in the way they had ostensibly committed themselves to. See, e.g., Siebecker, supra note 138. 
again) selling items produced with child labor, ${ }^{224}$ or that Wal-Mart was (once again) busting unions, ${ }^{225}$ it would be a very different matter to discover that Ben and Jerry's, a company that made its image on wholesome ingredients and progressive causes, was actually involved in abusing cows. ${ }^{226}$ It would also be a very different matter if executives at Patagonia, which has built its reputation as promoting conservation and stewardship of the environment, engaged in illegal dumping of chemicals in national forests. ${ }^{227}$ One comes to have these differing expectations based on the company's past actions, but to be sure, much of our collective knowledge about companies and their actions is predicated on what a particular firm chooses to tell the public.

Over the years, activists and consumer watchdogs have noted that certain CSR claims were potentially subject to overstatement, inflation, or even outright deception. Some environmental groups felt that the "green" label or "green" advertising was being used in ways that were either specious or misleading, by companies that had little to no investment in positive environmental practices. ${ }^{228}$ Colorfully, they termed these shallow advertising practices and misleading CSR statements "greenwashing." Increasingly, however, as many environmental groups benefited financially from corporate donations, it was the more radical groups, such as Greenpeace, who continued their critique of environmental CSR programs. ${ }^{229}$

Legal scholars who are well known for their expertise in the area of CSR have already noted the problems that could arise from greenwashing. Given the norms surrounding short-term profit

224. See, e.g., Robin Farmer, Protesters Cite Labor Practices, RichMOND TimeS DisPATCH, Nov. 10, 1996, at B1 (describing labor problems with Kathy Lee Gifford's clothing line as well as sweatshops used by Guess).

225. See Catherine L. Fisk \& Michael M. Oswalt, Preemption and Civic Democracy in the Battle over Wal-Mart, 92 MinN. L. REV. 1502 (2008); Nelson Lichtenstein, How Wal-Mart Fights Unions, 92 MinN. L. REv. 1462 (2008).

226. See, e.g., Christopher Gergen \& Stephen Martin, Social Responsibility Doesn't Have To Hurt Profits, News \& OBSERVER, Aug. 15, 2010, http://www.newsobserver.com/ 2010/08/15/628275/social_doesnt_have.html ("Ben and Jerry's became a poster-child for the movement when it promised 7.5 percent of pre-tax profits to help causes such as preserving the Amazonian rain forest.").

227. See, e.g., L.D. Porter, Eco-Fashion Takes the Runway, SANTA BARBARA InDEP., Apr. 29, 2010, at 25 (quoting the company's mission statement: "Build the best product, cause no unnecessary harm, use business to inspire and implement solutions to the environmental crisis").

228. Cf. Wright, supra note 5.

229. See, e.g., John Vidal, Artists Prepare for BP Protest at Tate Britain, GuARDiAn U.K., June 25, 2010, available at 2010 WLNR 12736937. 
maximization, companies have an incentive to promise consumers "eco-friendly" products, but then deliver goods or services in the cheapest way possible, regardless of environmental impact. While that may be an extreme or blatant scenario, the incentive to shirk duties described in advertising to an uncertain constituency outside the company (the environment) is unfortunately present. Indeed, because of these issues, there have been calls for both more disclosure of the true state of a company's environmental record and for the creation of a remedy for fraudulent or misleading claims of CSR.

Approximately ten years ago, Professor Cynthia Williams wrote an article in the Harvard Law Review, arguing that the SEC should require accurate and standardized disclosure of environmental information from publicly-traded companies. ${ }^{230}$ More recently, Professor Michael Siebecker noted that, much as it is difficult to test the truth of CSR advertising, commercials and the social responsibility reports that some companies have issued could mislead investors. ${ }^{231}$ And in a recent article that appeared two years ago, Professor Janet Kerr began sketching some preliminary contours of what an action under 10b-5 for what we term "faux CSR" might look like. ${ }^{232}$

While creative, the law review literature to date has largely described these issues only in the abstract. In addition, scant attention seems to have been devoted to this type of action for faux CSR in reported case law, although we will describe the few extant cases in detail, below. Because these legal theories regarding faux CSR and greenwashing are still novel, and because they may prompt a move toward a more substantive theory of CSR, thorough analysis of these issues is needed. Here, we find that the BP case study is a useful

230. Williams, supra note 9, at 1293-1306 (proposing that SEC mandate disclosure of environmental information, thus providing a check against inflated advertising claims).

231. Siebecker, supra note 9.

232. Kerr, supra note 9. Some of Professor Kerr's other proposals are far more radical. For example, in a 2009 article, she argues that the government might want to choose to mandate CSR in some instances, for example when a multinational corporation engages in various functions in a third-world country that make it more akin to a government than a corporation. Janet E. Kerr, A New Era of Responsibility: A Modern American Mandate for Corporate Social Responsibility, 78 U. Mo. KAN. CITY L. REV. 327 (2009); see also David Monsma \& John Buckley, Non-Financial Corporate Performance: The Material Edges of Social and Environmental Disclosure, 11 U. BALT. J. ENVTL. L. 151 (2004) (arguing that corporate statements about the extent of their CSR programs could in some instances be material). Other commentators have noted that corporate "codes of ethics" could also potentially be subject to liability as a form of false advertising if the company's executives fail to comply with the codes. See, e.g., Su-Ping Lu, Note, Corporate Codes of Conduct and the FTC: Advancing Human Rights Through Deceptive Advertising Law, 38 Colum. J. TRANSNAT'L L. 603 (2000). 
example for application of some of the ideas that have been set out before only theoretically.

Therefore, if a company advertises its record on CSR, highlighting an aspect or element of the company that is progressive, but downplaying a portion of the record that is anything but responsible, such as BP's pipeline accidents and refinery explosions, could that company be held legally liable for misleading consumers or investors? We propose several solutions, based on the constituency involved: that of false advertising (for consumers) and that of securities fraud (for investors). We then go on to discuss whether there may be a remedy to be found in newly enacted legislation present in the Dodd-Frank Act, which created a separate federal administrative agency to assist consumers with their investments, the Bureau of Consumer Financial Protection. We examine each of these possible causes of action in more depth, but the point is the same: CSR, to be meaningful, must be both genuine and substantive; some methods of policing claims of CSR are needed to protect the accuracy of information in the securities markets.

\section{False Advertising}

Were consumers led astray by BP's various commercials, print advertisements, and other materials that emphasized the company's ostensibly positive environmental reputation? In some ways this claim is slightly different from a typical "false advertising" claim about a good or service. For tangible goods, a positive reputation may be one that emphasizes durability, good value, functional design, or quality craftsmanship. For services, this may encompass efficiency, innovation, good ethics, or timeliness. In the instance of promoting a product that is essentially fungible - every gallon of gas is fundamentally interchangeable - one would not normally think about environmental impact as being a price differentiator.

That, however, was the genius of the "Beyond Petroleum" campaign; a particular brand of gasoline was sold based on a consumer preference for an environmentally friendly energy company. Regardless of whether this was an oxymoron, a fundamental incompatibility, or proof that the American public is willing to delude itself, the point is that it worked; BP spent $\$ 200$ million on its advertising campaign in order to promote this very idea. In some sense, BP was selling its green image as much as it was selling its gasoline. It was more than a press release or even a mere advertising 
campaign; as described above, it was a key part of their corporate strategy, identity, and branding.

While reported cases based on a theory of faux CSR are difficult to find, there have been some cases of false advertising brought in regard to specific products, mostly goods that used particular product labeling that asserted the good was "green." As noted by two commentators, there have been some successful claims in which insecticide companies labeled their products as safe or environmentally friendly, when they were not. ${ }^{233}$ In addition, cases have also been brought based on the use of the word "recycled," "recyclable," or "biodegradable," all of which now have strict legal definitions. ${ }^{234}$ Although these cases dealt with false representation claims concerning product labeling, the claim of false advertising around an environmental claim could be seen as analogous.

The most well-known claim of false advertising around a claim related to CSR is the California Supreme Court decision in Nike v. Kasky. ${ }^{235}$ In this case, which generated a good deal of attention-at one point the Supreme Court of the United States was to review the case before certiorari was ultimately withdrawn - the issue of corporate free speech conflicted with claims of labor abuses. In brief, media reports and press releases by various labor watchdogs asserted that Nike had violated various labor rights norms in the manufacture of its apparel, including violating minimum wage laws in various Asian countries, as well as subjecting workers to harassment and toxic substances. ${ }^{236}$ In response to these assertions, Nike denied that the problems existed. ${ }^{237}$ Plaintiffs brought an action under California's false advertising law against Nike for making these assertions, and the lower courts had summarily dismissed their actions on free speech grounds. ${ }^{238}$

Holding that Nike's assertions were commercial speech and thus subject to a lower level of constitutional protection, the California Supreme Court remanded the case for further factual findings to see if Nike's statements were, indeed, false. ${ }^{239}$ As the Nike court stated:

233. Branson, supra note 8, at 646 (citing cases); John M. Church, A Market Solution to Green Marketing: Some Lessons from the Economics of Information, 79 MinN. L. REV. 245, 301-04 (1994) (same).

234. Church, supra note 233, at 279-83.

235. 45 P.3d 243 (Cal. 2002), cert. granted, 539 U.S. 654 (2003).

236. Id. at $247-48$.

237. Id. at 248 .

238. Id.

239. Id. at 262 
Our holding, based on decisions of the United States Supreme Court, in no way prohibits any business enterprise from speaking out on issues of public importance or from vigorously defending its own labor practices. It means only that when a business enterprise, to promote and defend its sales and profits, makes factual representations about its own products or its own operations, it must speak truthfully. ${ }^{240}$

The case later settled out of court with Nike's promising to fix various issues, subject itself to third-party monitoring, and make a monetary payment to a worker's advocacy nonprofit group. While many commentators have discussed Nike as a promising avenue to keep corporations to their word regarding worker rights, it is more tantalizing than fulfilling, as the issue itself was never litigated and the Supreme Court of the United States never heard the case. ${ }^{241}$

With that said, the issue is likely an open one; but if "green" claims were a significant part of a company's consumer marketing, and consumers did, indeed, rely on the false statements, the corporation's claims would not be entitled to an absolute First Amendment free speech defense; instead they would only be accorded the (lesser) deference afforded to commercial speech. State governments retain the right to regulate commercial speech that is false or misleading, and this could pave the way for actions based on a claim of greenwashing or faux CSR.

\section{Securities Fraud}

Would investors who chose to put their money in BP stock, rather than another firm, be able to bring a cause of action for securities fraud on the basis of BP's misleading advertising campaign? We believe that the answer to this question should be "yes," and we believe that allowing such a claim to proceed would increase the overall accuracy of information available about CSR.

240. Id. at 247.

241. For a sampling of commentary about the impact of Nike, see, for example, Robert L. Kerr, From Sullivan to Nike: Will the Noble Purpose of the Landmark Free Speech Case Be Subverted To Immunize False Advertising, 9 CoMM. L. \& PoL'y 525 (2004); Tamara R. Piety, Grounding Nike: Exposing Nike's Quest for a Constitutional Right To Lie, 78 TEMP. L. REV. 151 (2005); Michele Sutton, Between a Rock and a Judicial Hard Place: Corporate Social Responsibility Reporting and Potential Legal Liability Under Kasky v. Nike, 72 U. Mo. Kan. City L. REv. 1159 (2004); Samuel A. Terilli, Nike v. Kasky and the Running-butGoing-Nowhere Commercial Speech Debate, 10 CoMM. L. \& POL'y 383 (2005); David C. Vladeck, Lessons from a Story Untold: Nike v. Kasky Reconsidered, 54 CASE W. RES. L. REV. 1049 (2004). 
Securities fraud under Section 10(b) and Rule 10b-5 requires that a plaintiff show a material misstatement or actionable omission of fact, made with scienter, on which another justifiably relies, causing damages. ${ }^{242}$ Securities fraud additionally requires that the fraud be "in connection with the purchase or sale of any security" per the statute, ${ }^{243}$ if the security is traded on an efficient market such as the New York Stock Exchange, reliance can be presumed under the "fraud-on-themarket theory"; ${ }^{244}$ and, regarding causation, the plaintiff must show both that the misstatement or omission caused the purchase or sale (transaction causation) and that the misstatement or omission caused the complained-of loss (loss causation). ${ }^{245}$

A United States Court of Appeals for the Sixth Circuit case raises the key obstacle that plaintiffs will likely face in bringing an action for CSR fraud under the securities laws: showing materiality. ${ }^{246}$ In the Sixth Circuit case, Ford was charged with securities fraud for its statements regarding the safety of the tires installed on the Ford Explorer. ${ }^{247}$ Plaintiffs noted that they were in part suing Ford for representing itself as a socially responsible company while marketing products that were dangerous. ${ }^{248}$ The court there dismissed the claim, stating the following about Ford's claim that it was "going to lead in corporate social responsibility":

Such statements are either mere corporate puffery or hyperbole that a reasonable investor would not view as significantly changing the general gist of available information, and thus, are not material, even if they were misleading. All public companies praise their products and their objectives. Courts everywhere "have demonstrated a willingness to find immaterial as a matter of law a certain kind of rosy affirmation commonly heard from corporate managers and numbingly familiar to the marketplace-loosely optimistic statements that are so vague, so lacking in specificity, or so clearly constituting the opinions of the

242. Compare W. Page Keeton et al., Prosser \& Keeton on the LaW of Torts $\S 105$ (5th ed. 1984) (common law fraud), with Basic, Inc. v. Levinson, 485 U.S. 224, 231-32 (1988) (fraud action under section 10B and Rule 10b-5), and Dura Pharms., Inc. v. Broudo, 544 U.S. 336, 341-42 (2005) (same).

243. 15 U.S.C. $\S 78 \mathrm{j}(\mathrm{b})(2006)$.

244. Basic, 485 U.S. at 241-48.

245. Dura Pharm., 544 U.S. at 341-42 (distinguishing between transaction and loss causation)

246. In re Ford Motor Co., 381 F.3d 563, 570-71 (6th Cir. 2004); see also Monsma \& Buckley, supra note 232; Kerr, supra note 9, at 857.

247. Ford, 381 F.3d at 570-71.

248. Id. at 570 . 
speaker, that no reasonable investor could find them important to the total mix of information available."249

And, indeed, one of the concerns or problems that investors bringing an action against a company like BP might face is that it might be difficult to point to one fact specifically identified as false, or, even if that were easy to prove, that the statement was material. ${ }^{250}$

However, as socially conscious investing increases in volume and popularity, the materiality hurdle may not seem so insurmountable. ${ }^{251}$ As two commentators noted, a

large institutional investor or a class of socially responsible mutual funds may have a more objective basis for relying on non-financial company statements, policies, and practices. In other words, once a company states a position on climate change or child labor, there is no going backwards in the marketplace without first retracting or reestablishing performance expectations once they are made. ${ }^{252}$

Such funds explicitly make their investment decisions based on the triple bottom line. In light of these investment criteria, it becomes difficult to say that CSR would be anything else other than material to the investment decision.

As the BP oil spill demonstrates, it should be possible for a plaintiff to show both transaction and loss causation to support a securities fraud claim for false CSR representations. An investor who chose BP stock on the strength of its carefully cultivated green reputation should be able show transaction causation. The representations also relate to BP's stock performance following the spill, in recognition of the company's massive exposure for the environmental and economic damage it caused to the Gulf and regional economy. Thus, loss causation also seems to be present. The same showing could not be so easily made on less compelling facts; where an investor is merely duped by greenwashing claims but no related damages result, loss causation would be absent and thus the claim for CSR fraud would likely fail.

249. Id. at 570-71 (citations omitted) (internal quotation marks omitted).

250. On puffery generally, see David A. Hoffman, The Best Puffery Article Ever, 91 IOWA L. REv. 1395 (2006).

251. See George Djurasovic, The Regulation of Socially Responsible Mutual Funds, 22 J. CORP. L. 257 (1997).

252. Monsma \& Buckley, supra note 232. 


\section{The Dodd-Frank Act and the Bureau of Consumer Financial Protection}

While these theories under either false advertising or Rule 10b-5 could be helpful in analyzing liability for faux CSR, there is another possibility for policing CSR claims on the horizon. In July of 2010, Congress passed a historic financial reform bill, known as the DoddFrank Act after its sponsors. ${ }^{253}$ Running to over 840 printed pages, the Dodd-Frank Act covers matters as diverse as the regulation of the banking system, executive compensation, and the regulation of derivative swaps. One of the portions of the Dodd-Frank that will likely have a large impact on consumers is the establishment of the Bureau of Consumer Financial Protection. Harvard Law School Professor Elizabeth Warren was a critical figure in shaping the course of the legislation and establishing the need for additional consumer protection in response to the credit meltdown and the series of bailouts in $2008 .^{254}$ Section 1011 of the Dodd-Frank Act sets out the enabling legislation for the establishment of the Bureau, which is to "regulate the offering and provision of consumer financial products or services under the Federal consumer financial laws., ${ }^{255}$

Other subsequent sections describe the Bureau's mission to increase the provision of financial services in underserved neighborhoods, ${ }^{256}$ establish an Office of Fair Lending and Equal Opportunity, ${ }^{257}$ establish an Office of Financial Education, and "develop and implement a strategy to improve the financial literacy of consumers." 258 Two of the Bureau's enumerated objectives are to ensure that consumers are "provided with timely and understandable information to make responsible decisions about financial transactions" and that consumers are "protected from unfair, deceptive,

253. Dodd-Frank Wall Street Reform and Consumer Protection Act, Pub. L. No. 111203, 124 Stat. 1376, 1964 (2010); see also Hal S. Scott, The Reduction of Systemic Risk in the United States Financial System, 33 Harv. J. L. \& PuB. POL'y 671 (2010) (discussing proposed legislation that became the Dodd-Frank Act).

254. Jonathan Alter, Pick Elizabeth Warren, Obama Should Relish the Fight, NEwSWEEK, Aug. 9, 2010, http://www.newsweek.com/2010/08/01/pick-elizabethwarren.html (advocating for Professor Warren's appointment to head the agency she lobbied to create); Harold Meyerson, Jobs in the Cards?, WASH. Post, Aug. 4, 2010, at A17 (same); Damian Paletta, Consumer-Czar Candidate Waits in Wings, WALl ST. J., Aug. 2, 2010, at A4.

255. Pub. L. No. 111-203, tit. X, § 1011, 120 Stat. at 1964.

256. Id. § 1013(b)(2) (Community Affairs Office).

257. Id. $\S 1013(\mathrm{c})$.

258. Id. $\S 1013(\mathrm{~d})$. There is also provision for an Office of Service Member Affairs, section 1013(e), as well as one for older Americans. Id. § 1013(g). 
or abusive acts and practices and from discrimination.259 The Bureau will be primarily concerned with researching and policing consumer credit agreements, loans, mortgages, and other financial instruments that can often be incredibly confusing to consumers.

At the same time, the language in the statute concerning consumer education, appropriate disclosure, and tracking of consumer complaints could overlap with the area of "faux CSR" or "greenwashing," as these are consumer information issues and accurate disclosure could certainly influence a consumer's informed investment decision. Further, in the process of providing consumers with education and knowledge about their rights, it would be wise to help consumers understand whether a purchase (for altruistic reasons) is actually going to advance the cause that they believe in, and that can only be done through accurate disclosure of information. Because the legislation and the Bureau are so new, it is difficult to know how various provisions will be enforced or what litigation will be brought. That said, it is intriguing to think about the possibility that accurate CSR information could be one aspect of consumer fraud that might receive attention from the new agency.

\section{A Private Certification Model}

Alternatively or in conjunction with the avenues described above, private mechanisms can also serve to police corporate claims of social responsibility. Before the U.S. Department of Agriculture organic label was introduced, private organizations such as Quality Assurance International played a central role in certifying organic food claims ${ }^{260}$ Organic food purveyors would contact one of these certifiers who would then inspect and verify any organic food claims according to each organization's specific standards. In 2002, the U.S.D.A. developed uniform standards for organic food and empowered these organizations (and state departments of agriculture) to certify and label products as U.S.D.A. organic. ${ }^{261}$

The organic food example suggests two additional models for policing CSR claims. Private organizations could develop marks and

259. Id. § 1021(b).

260. See QuAlity AsSURANCE InTERnATIONAL, http://www.qai-inc.com (last visited Feb. 27, 2011); OREGON TILTH, http://tilth.org/about (last visited Feb. 27, 2011).

261. See Federal Organic Foods Production Act of 1990, 7 U.S.C. $\S \S 6503-6504$ (2006); 7 C.F.R. $\S \S 205.1-205.690$. Similar private certification systems exist for kosher food and for green "LEED certified" buildings. See, e.g., OUKOSHER, http://www.oukosher.org (describing the O-U hechsher and mark); U.S. GREEN BuILDING COUNCIL, http://www. usgbc.org/leed (last visited Feb. 27, 2011) (describing the LEED building designations). 
license corporations to use them upon verification of any social responsibility claims. In fact, B Labs, the owner of the "B Corporation" mark, already offers a similar service, certifying and licensing corporations that adhere to its standard of benevolence. ${ }^{262}$ Alternatively, the Bureau of Consumer Financial Protection or another federal agency could develop uniform CSR standards, as was done with organic food, and designate private organizations to verify compliance with them. Or perhaps, the Bureau could allow private entities to do this verification on their own, but audit any such certification-providers so as to ensure they are not subject to bribery or manipulation. Such monitoring or other certification could alleviate "greenwashing" concerns about companies claiming to be socially responsible but doing little beyond clever marketing.

\section{Counterarguments and Rebuttal}

We anticipate that some of our proposals will have their critics, especially in light of the fact that these are novel legal theories as applied to CSR. From the right, the critique would likely concern expanded liability and an increased cost to businesses associated with compliance. While we understand the hesitation to expand liability, in our minds it is outweighed by the competing importance of market efficiency. In a securities market crowded with meaningless greenwashing "noise," it becomes difficult for investors to receive accurate information about CSR and for arbitrageurs to trade and have the market self-correct. To the extent that regulation in and of itself is a concern, there is also the option of leaving more of the policing to private certification organizations.

From the left, the critique might be that our proposals have not gone far enough to regulate, or even in some instances, mandate, particular standards for CSR. ${ }^{263}$ Further, some would say that our proposals put too much faith in individual consumer and investor choice. To this we would respond that here we are concerned with the value of transparency to investors and consumers. While investors and consumers retain the ability to invest and spend as they wish, they also deserve the right to be accurately informed about CSR-related matters in addition to the financial bottom line.

We also believe there may be an argument-from those sympathetic to CSR regardless of ideological position-that the

262. Sneirson, supra note 156, at 1017-19.

263. Kerr, supra note 9; see discussion supra note 232. 
proposals might deter some amount of CSR from those firms on the margin. As CSR is a voluntary endeavor, the argument would be that liability for misstatements or the additional costs of certification could discourage some number of firms from implementing CSR programs. $^{264}$

While in general we would not wish to deter companies from becoming more socially responsible, at the same time we also have to acknowledge the seriousness of greenwashing. In fact, we would go so far as to argue that if greenwashing goes unchecked, the CSR project will be fatally undermined. Without some form of verification, the "free riders" who take advantage of CSR will result in a public weary of hearing about CSR and skeptical of or even cynical about its benefits. As Professors Conley and Williams have noted, faux CSR may be worse than no CSR, as faux CSR "may be even worse than business as usual, as the effect of the rituals may be to co-opt critics, mislead consumers, and preempt regulation.",265 Or, as Professor Siebecker wrote:

[A]bsent trustworthy auditing processes, enforcement mechanisms, or robust disclosure requirements that ensure full transparency, it becomes difficult for consumers and investors to detect when a company in fact adopts a defective posture. What results is true economic waste- $\mathrm{a}$ destruction of the market for good CSR practices, because consumers and investors will not be willing to pay a premium for CSR practices, unless they can rely on the accuracy of a corporation's statements. ${ }^{266}$

Therefore, despite understanding the hesitancy to hold corporations accountable or liable for statements that may, in some instances, be merely aspirational, if this information is being relied on by consumers and investors, they do have the right to full information. Surely those who drove out of their way to fill up at BP because of its advertising or find themselves with BP stock in their portfolio because they thought

264. Brown, supra note 135 , at 374 :

The solution that this Article will consider is for the states or the federal government or both to adopt laws that would grant corporations who adopt aspirational codes of conduct a safe harbor from litigation that might be brought if they fail to meet the higher standards set forth in their codes. Corporations would only be entitled to these safe harbors as long as they adopted and monitored the implementation of such codes in good faith.

265. John M. Conley \& Cynthia A. Williams, Engage, Embed, and Embellish: Theory Versus Practice in the Corporate Social Responsibility Movement, 31 J. CORP. L. 1, 14-15 (2005).

266. Siebecker, supra note 138 , at 118-19. 
it was an environmentally friendly company would have liked to have had more complete information, rather than corporate blandishments.

The final criticism is that none of our proposed solutions, standing in isolation, will remove all of the faux CSR from the market. While we acknowledge that the false advertising and securities fraud solutions do not completely map to CSR, given that these causes of action were originally shaped to remedy other concerns, they at least provide good starting points for eliminating the worst or most egregious instances of faux CSR.

\section{B. Reforming Profit Maximization}

A final set of suggestions involves corporate law's focus on shareholder profits. As the preceding sections show, corporate law provisions requiring a shareholder focus in everyday decisionmaking go largely unenforced and serve little purpose beyond perpetuating the shareholder maximization norm and stifling CSR. ${ }^{267}$ What is more, this singular focus may even disserve the very shareholders it is meant to benefit if recent financial scholarship is correct that a broader, longer-term view is what best enhances firm value. ${ }^{268}$

To the extent that nothing requires corporate fiduciaries to maximize shareholder returns, no concrete corporate law reforms need be undertaken. Perhaps all that is necessary is a greater awareness among academicians, lawyers, and businesspeople that firms may heartily integrate socially responsible principles and practices without breaching any duty, without disappointing shareholders over the long term, and without violating modern social norms.

Those firms wishing to do so may of course continue to pursue shareholder profits to the exclusion of other constituencies' interests, but they must obey applicable laws and regulations in the process. In other words, we must abandon the law-as-price view of compliance with corporate legal obligations, such that corporations uninterested in social responsibility at least rise to the level of bare compliance. Others have analyzed the issue in more depth than we do here, and we refer to and endorse their proposals here. ${ }^{269}$

267. See supra Part IV.C.

268. See discussion supra note 151 and accompanying text.

269. See, e.g., GREENFIELD, supra note 187, at 73 (viewing noncompliance with legal obligations as ultra vires actions); Williams, supra note 186, at 1385 (arguing that firms should make serious efforts to obey applicable laws or work to change those laws). 


\section{CONCLUSION}

Over the next decade, as the environmental effects of the BP oil spill finally fade into history, ${ }^{270}$ will business continue as before, its profit focus unchanged and its commitment to CSR still little more than a cheap-talk marketing gimmick? ${ }^{271}$ We hope not; we hope that one positive result from the disaster will be lasting changes to corporate law and practice encouraging firms to engage in genuine, more substantive forms of CSR. These changes may be as simple as widespread recognition that corporate fiduciaries need not focus on shareholder profits to the exclusion of all other considerations and meaningful enforcement of labor and environmental laws. And as the BP case study demonstrates, true change must coincide with some means of substantiating corporate claims of social responsibility. Traditional avenues of false advertising and securities fraud can serve this purpose, as can elements of the Dodd-Frank Act, either in conjunction with or separately from the actions of private certification organizations. We hope that these proposals are able to effect real change, instilling greater social responsibility in Anglo-American businesses and allowing them to move themselves "beyond profit."

270. See Robert Lee Hotz, Much Oil Remains in Gulf, Researchers Estimate, WALL ST. J., Aug. 17, 2010, http://online.wsj.com (enter "much oil remains in gulf" in search bar, with quotes) (estimating it will take years before the spilled oil completely degrades).

271. Jason Scott Johnston, Communication and Courtship: Cheap Talk Economics and the Law of Contract Formation, 85 VA. L. REV. 385 (1999). 